\title{
Carbon release and cycling within epilithic biofilms in two contrasting headwater streams
}

\author{
Susan E. Ziegler ${ }^{1, *}$, David R. Lyon ${ }^{2}$, Sherri L. Townsend ${ }^{2,3}$ \\ ${ }^{1}$ Department of Earth Sciences, Memorial University, 4063 Alexander Murray Building, St. John's, \\ Newfoundland and Labrador A1B 3X5, Canada \\ ${ }^{2}$ Environmental Dynamics Program, University of Arkansas, 113 Ozark Hall, Fayetteville, Arkansas 72701, USA \\ ${ }^{3}$ Faculty of Science, North Arkansas College, 1515 Pioneer Drive, Harrison, Arkansas 72601, USA
}

\begin{abstract}
This study investigates the release of dissolved organic carbon (DOC) from epilithic biofilms and how the exchange of $\mathrm{C}$ between epilithic algae and bacteria varies between 2 contrasting headwater streams. During 3 seasons, light and dark enclosures were incubated in situ with rock substrate and stream water amended with ${ }^{13} \mathrm{C}$-labeled bicarbonate to follow newly fixed carbon into DOC, epilithic biofilm, and biofilm phospholipid fatty acids (PLFAs). Net release of DOC only occurred in the light enclosures and was significantly affected by net primary production (NPP). However, the net release of DOC as a proportion of NPP increased with light availability and decreased with dissolved inorganic nitrogen in Huey Hollow, the nutrient-deplete stream, and decreased with dissolved inorganic phosphorus (DIP) in Moore Creek, the nutrient-replete stream. Newly-fixed C, released as DOC, decreased with DIP but represented a greater proportion of net DOC release in Moore Creek (6 to $15 \%$ ) relative to that in Huey Hollow (0.7 to $2 \%$ ). Congruently, the quantity of newly-fixed $\mathrm{C}$ retained in the bulk biofilm and the bacterial PLFA ia15:0 increased together with DIP. Further, the proportion of NPP incorporated into bacterial PLFA in Huey Hollow was 4 times that in the Moore Creek biofilms, suggesting that bacteria accessed relatively more NPP in the low nutrient stream biofilms. Our data indicate that $\mathrm{C}$-cycling differed between the contrasting streams in 2 significant ways. A larger proportion of DOC released from biofilms in the nutrient-rich stream was derived from new photosynthates, reducing the availability of this source of NPP to biofilm bacteria. Concurrently, a greater proportion of NPP was retained in heterotrophic bacterial PLFAs in the more nutrient-deplete stream biofilms. These results suggest that nutrient levels can greatly affect the source and processing of DOC, and emphasize the need to understand the mechanisms responsible for varied DOC cycling and transport in streams.
\end{abstract}

KEY WORDS: Carbon cycling - Dissolved organic carbon - Epilithic biofilms - Bacterial-algal interaction $\cdot$ Phospholipid fatty acids $\cdot$ Headwater streams

Resale or republication not permitted without written consent of the publisher

\section{INTRODUCTION}

Headwater streams are key locations for nutrient and organic matter processing within watersheds due to their large substrate surface area relative to water volume, a feature that exerts a strong effect on the downstream export of nutrients and organic matter (Peterson et al. 2001). Microbial biofilms associated with these surfaces are responsible for much of the nutrient uptake and transfer to higher trophic levels in headwater streams (Dodds et al. 2000). Stream biofilms are composed of a consortium of algae, bacteria, meiofauna and detritus embedded in a polysaccharide matrix (Haack \& McFeters 1982, Lock et al. 1984), the structure of which can alter the exchange of stream water nutrients. Variation in access to substrates for microbial activity can occur across the biofilm interior and perimeter, and the dependency of heterotrophic bacteria on organic carbon supplies from algae and cyanobacteria can be relatively high (Murray et al. 
1986, Neely \& Wetzel 1995). These attached communities, however, do respond readily to external forces such as nutrient availability in stream water (Bothwell 1985, Lohman et al. 1991, Stelzer \& Lamberti 2001).

Although phototrophic components of stream biofilms readily respond to nutrient additions, the extent of nutrient cycling in headwater streams is typically dependent upon the availability of dissolved organic matter (DOM) for heterotrophic use (Bernhardt \& Likens 2002). The quantity and quality of DOM can vary within and among streams (Volk et al. 1997) and can greatly affect microbial biomass (Warren et al. 1964, Bott et al. 1984) and activity (Kaplan \& Bott 1983), as well as biogeochemical cycling in streams. Dissolved organic carbon (DOC) quality and quantity, for example, control nutrient cycling in both the subsurface (Findlay et al. 1993, Sobczak et al. 1998, Baker et al. 1999) and surface environment, stressing the important link between $\mathrm{C}$ and $\mathrm{N}$ cycling in forested streams (Bernhardt \& Likens 2002). Autochthonous sources of DOC can be more bioavailable than some allochthonous sources (Battin et al. 1999), supporting the evidence that heterotrophic bacteria in streams readily degrade algal exudates (Cole et al. 1982, Kaplan \& Bott 1989). The proportion of bioavailable DOC represented by identifiable components in stream water, however, is low relative to other aquatic ecosystems and may reflect the larger contribution of highly degraded allochthonous DOC, particularly in forested streams (Benner 2003).

DOC source and composition probably influence the linkage between bacteria and algae, thereby affecting the function of stream biofilms. A limited number of studies have examined algal-bacterial interaction within biofilms (Murray et al. 1986, Espeland \& Wetzel 2001, Scott et al. 2008) particularly in streams (Romani \& Sabater 2000, Scott et al. 2008, Lyons \& Ziegler 2009). Algal exudates in stream biofilms can stimulate bacterial activity (Romani \& Sabater 2000, Ishida et al. 2007). On the other hand, increased algal-bacterial coupling could lead to greater release of DOC through microbial reworking of terrestrial organic matter stimulated by algal exudates. These potentially interacting mechanisms highlight our lack of understanding of variation in DOC and nutrient cycling within headwater stream biofilms, and of the influence these biofilms exert on stream water DOC source and composition.

As part of a larger study characterizing the source, composition and bioavailability of DOC in 2 contrasting Ozark streams, recent studies reported low bioavailability of DOC in a stream heavily influenced by surrounding agricultural lands (Moore Creek) despite luxurious algal growth (Brisco \& Ziegler 2004, Ziegler \& Brisco 2004). These experiments suggested that elevated nutrient concentrations probably sup- ported increased levels of microbial activity, resulting in a larger pool of refractory DOC relative to pools of DOC in a more nutrient-deplete stream surrounded by intact forests (Huey Hollow) (Brisco \& Ziegler 2004, Ziegler \& Brisco 2004). Increased nutrient availability can stimulate microbial degradation of terrestrial organic matter and subsequently increase the release of humics (Kaplan \& Newbold 1993) and the uptake of more labile DOC (Moran \& Hodson 1989). The variation in source and bioavailability of DOC in Moore Creek and Huey Hollow suggests that different processes may be responsible for the release and processing of DOC in these streams. In the present study, we expand on our previous findings at Moore Creek and Huey Hollow by further characterizing DOC dynamics in the epilithic biofilms within these 2 headwater streams. Large advances in our understanding of carbon cycling within marine pelagic and benthic microbial communities have been gained through the use of ${ }^{13} \mathrm{C}$-labeling or probing (Boschker \& Middelburg 2002). Here, we employ a ${ }^{13} \mathrm{C}$-labeling approach to specifically assess: (1) the relative role of the epilithic biofilm (BF) in generating DOC, (2) potential sources of DOC released from epilithic biofilms, and (3) how the exchange of $\mathrm{C}$ between algae and bacteria varies within the epilithic biofilms of these 2 streams.

\section{MATERIALS AND METHODS}

Study sites. Samples were collected from and incubated at mid-stream sites in 2 headwater streams located in northwest Arkansas, USA. The forested and less affected stream used in the present study, Huey Hollow, is approximately $5.6 \mathrm{~km}$ in length and drains an 1130 ha watershed, dominated by hardwood deciduous forest, and is underlain by limestone. Moore Creek, the more nutrient-affected stream, is approximately $8.4 \mathrm{~km}$ long, drains a 2120 ha watershed dominated by agricultural pasture and is underlain by shale and sandstone. The substrate of both streams is primarily bedrock and small boulders, and the soils are ultisols, primarily of the order Typic Hapludults. Moore Creek was chosen as an affected stream based on nutrient monitoring and continuous flow and discharge data. Both streams have been part of ongoing studies of the factors regulating stream DOM source and cycling (Brisco \& Ziegler 2004, Ziegler \& Brisco 2004).

Field enclosure experiments. We performed experiments at each of the 2 stream sites in winter, spring and late summer 2003. Two 301 carboys of stream water were collected and spiked with a solution of $\mathrm{NaH}^{13} \mathrm{CO}_{3}(\sim 5000 \%)$ to increase the $\delta^{13} \mathrm{C}$-dissolved inorganic carbon (DIC) of the stream water to approxi- 
mately 800 to $1000 \%$ while increasing the ambient DIC concentration by less than $20 \%$. The carboys were stored in the dark overnight at ambient temperature to allow the inorganic carbon pool of the water to equilibrate. The following morning rock substrate, representative of the typical size, surface area and biofilm colonization of the natural substrate, was collected from the stream and randomly distributed into 3 transparent and 3 opaque 121 polycarbonate enclosures. These polycarbonate enclosures were previously tested using low-DOC deionized (DI) water incubated with circulation for $24 \mathrm{~h}$ and found to be free of detectable DOC contamination. An additional set of rocks, immediately sub-sampled from those used in the enclosures, were collected for initial biofilm properties (total mass, \% C, $\% \mathrm{~N}, \delta^{13} \mathrm{C}, \delta^{15} \mathrm{~N}$, phospholipid fatty acid [PLFA] concentration and PLFA $\delta^{13} \mathrm{C}$ ) by scrubbing with a brush, rinsing with distilled water and storing the slurry in clean amber plastic bottles on ice until transported to the laboratory where samples were lyophilized. The ${ }^{13} \mathrm{C}_{\text {DIC }}$ $\left(\mathrm{DI}^{13} \mathrm{C}\right)$ enriched stream water was measured and dispensed into each enclosure. Stream water was circulated within the individual enclosures using silicone tubing and individual peristaltic pumps. After $15 \mathrm{~min}$ of circulation, initial measurements of temperature, dissolved oxygen (DO) and $\mathrm{pH}$ were taken withYSI550A and YSI-63 meters (YSI). Initial water samples were also collected for measurements of DIC, DOC, ammonium $\left(\mathrm{NH}_{4}{ }^{+}\right)$, nitrate plus nitrite $\left(\mathrm{NO}_{3}{ }^{-}+\mathrm{NO}_{2}{ }^{-}\right)$, soluble reactive phosphate (SRP), $\delta^{13} \mathrm{C}_{\mathrm{DOC}}$ and $\delta^{13} \mathrm{C}_{\mathrm{DIC}}$. The pumps were then restarted and the enclosures were allowed to incubate in situ for 7 to $9 \mathrm{~h}$, after which final measurements and samples for temperature, DO, $\mathrm{pH}, \mathrm{DIC}, \mathrm{DOC}, \mathrm{NH}_{4}{ }^{+}, \mathrm{NO}_{3}{ }^{-}$, SRP and $\delta^{13} \mathrm{C}_{\mathrm{DOC}}$ were collected. After final water sampling was complete, the entire biofilm community from each enclosure was collected for final biofilm properties as described above for the initial biofilm sample. The substrate from each enclosure was carefully rinsed with ambient stream water before collecting the biofilm to remove remaining ${ }^{13} \mathrm{C}_{\text {DIC }}$ associated with the enclosure stream water. Solar radiation measurements (photosynthetically active radiation $[\mathrm{PAR}], \mathrm{UVA}$ and $\mathrm{UVB}$ ) were taken at the top of the enclosures at the beginning of the incubation, within $1 \mathrm{~h}$ of solar noon, and end of the experiment with an IL1700 radiometer with SUD033 (PAR and UVA) and SUD240 (UVB) detectors (International Light).

To determine the importance of stream water respiration and net primary production (NPP), twelve $300 \mathrm{ml}$ BOD bottles were filled with stream water at the beginning of the incubation period. Four of the bottles were immediately fixed for DO determination by Winkler titration and the remaining bottles, half of which were wrapped with foil, were incubated in situ at a depth approximately equivalent to mid-depth in the enclosures. Following a 7 to $9 \mathrm{~h}$ incubation, these 8 light and dark bottles were also fixed for Winkler titration and transported back to the laboratory. All 12 bottles were analyzed for DO within $24 \mathrm{~h}$ using an automated titrator with potentiometric endpoint detection.

Enclosure experiment flux measurements. The experiments were designed to assess differences in the function of epilithic biofilms, specifically C cycling, between the 2 contrasting streams. Because of the high spatial variability of benthic substrate surface area, flux measurements per unit stream area or stream reach could not be adequately determined from the enclosure experiments. All flux measurements were, therefore, normalized to biofilm carbon $\left(\mathrm{C}_{\mathrm{BF}}\right)$ (e.g. net flux of DIC is reported in mmol C mol $\mathrm{C}_{\mathrm{BF}}{ }^{-1} \mathrm{~h}^{-1}$ ) to enable comparison of flux rates associated with the biofilm communities between the study sites and across seasons.

To track the fate of autotrophic $\mathrm{C}$ within the enclosures, we determined the proportion of $\mathrm{C}$ derived from that fixed during the incubation (termed 'newly-fixed $\mathrm{C}^{\prime}$ throughout) for the bulk biofilm and DOC released in each enclosure. The quantity of $\mathrm{C}_{\mathrm{BF} \text { (newly-fixed) was }}$ determined using:

$$
\begin{gathered}
F \mathrm{C}_{\mathrm{BF} \text { (newly-fixed) }}=\frac{\delta^{13} \mathrm{C}_{\mathrm{BF}(\text { final) }}-\delta^{13} \mathrm{C}_{\mathrm{BF} \text { (initial) }}}{\delta^{13} \mathrm{C}_{\mathrm{DIC} \text { (initial) }}-\delta^{13} \mathrm{C}_{\mathrm{BF} \text { (initial) }}} \\
\text { Total } \mathrm{C}_{\mathrm{BF} \text { (newly-fixed) }}=F \mathrm{C}_{\mathrm{BF} \text { (newly-fixed) }} \times \mathrm{C}_{\mathrm{BF} \text { (final) }}
\end{gathered}
$$

where $F_{\mathrm{BF} \text { (newly-fixed) }}$ is the fraction of $\mathrm{C}_{\mathrm{BF}}$ derived from newly-fixed $C$ during the incubation, $\delta^{13} C_{B F(i n i t i a l)}$ and $\delta^{13} \mathrm{C}_{\mathrm{BF} \text { (final) }}$ refer to the $\delta^{13} \mathrm{C}$ of the biofilm at the start of and after the incubation period, respectively, and $\delta^{13} \mathrm{C}_{\text {DIC(initial) }}$ refers to the $\delta^{13} \mathrm{C}$ of the DIC in the enclosure at the start of the incubation. Net DOC flux was estimated by the difference between initial and final DOC concentrations within enclosures during the course of the incubation. The fraction of net DOC flux from newly-fixed $\mathrm{C}$ during the incubation was estimated for all positive fluxes (release of DOC into stream water) by comparing the release of DOC derived from newly-fixed carbon with total net DOC release using the formula:

$$
\begin{gathered}
F C_{\text {DOC(newly-fixed) }}=\frac{\delta^{13} C_{\text {DOC(final) }}-\delta^{13} C_{\text {DOC(initial) }}}{\delta^{13} C_{\text {DIC(initial) }}-\delta^{13} C_{\text {DOC(initial) }}} \\
\% \mathrm{C}_{\text {DOC(newly-fixed) }}=\frac{\left[\mathrm{C}_{\text {DOC }}\right]_{\text {(final) }} \times F C_{\text {DOC(newly-fixed) }}}{\Delta\left[\mathrm{C}_{\text {DOC }}\right]} \times 100
\end{gathered}
$$

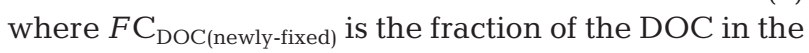
enclosure at the end of the incubation that was derived

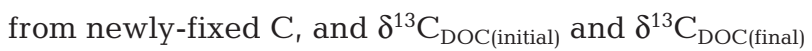


are the $\delta^{13} \mathrm{C}$ of the DOC at the start and end of the incubation, respectively. The estimates of the fraction of newly-fixed $\mathrm{C}$ may be conservative because the isotopic fractionation associated with the uptake and fixation of the DIC during the incubations was not included in our calculations. This factor can be governed by stream flow (France 1995). However, this source of error probably represents a small part of the change in $\delta^{13} \mathrm{C}$ of newly-fixed $\mathrm{C}$, given that $\delta^{13} \mathrm{C}_{\text {DIC }}$ pool was approximately 50 times the level of fractionation expected.

PLFA analysis. Total lipid extraction and lipid class separation were performed on biofilm samples to determine the concentration and $\delta^{13} \mathrm{C}$ of individual PLFAs. The biofilm slurries collected were shell frozen, lyophilized and picked through by hand to remove visible invertebrates and large pieces of terrestrial detritus. Lyophilized biofilms were extracted and lipid class separated according to White \& Ringelberg (1998) and saponified and derivatized to fatty acid methyl esters (FAMEs) according to Dobbs \& Findlay (1993). FAMEs were quantified by gas chromatography (GC) using a flame ionization detector (Agilent 6890) and identified with a GC-MS (Agilent 6890 and Agilent $5970_{\text {inert }}$ mass selective detector). The $\delta^{13} \mathrm{C}$ of individual PLFAs was determined by analyzing the FAMEs on a GC (Agilent 6890) interfaced via a GC/CIII (ThermoFinnigan) with a Deltaplus isotope ratio mass spectrometer (ThermoFinnigan). A correction for the addition of the methyl carbon from the $\mathrm{BF}_{3}$-methanol derivatization was calculated for each fatty acid by mass balance from the analysis of a mixture of 8 free and methylated fatty acids of known isotopic composition with each set of 6 samples. Stable isotopic ratios were measured relative to high purity, calibrated, and reference gas standards expressed relative to international standard PDB. All GCs used the same parameters and capillary column (50 m SGE BPX-70).

Polyunsaturated PLFAs (PUFAs; 16:2 $\omega 4,16: 2 \omega 6$, $18: 2 \omega 6,18: 3 \omega 3$ and $20: 5 \omega 3$ ) were attributed primarily to algae in the biofilms analyzed with $18: 3 \omega 3$ and 20:5 $\omega 3$ primarily attributed to green algae and diatoms, respectively (Wood 1988, Findlay \& Dobbs 1993). Terminally branched fatty acids (i15:0 and a15:0) were attributed to heterotrophic bacteria since they are not commonly found in cyanobacteria (Parker et al. 1967, Ahlgren et al. 1992). Likewise, PLFA 16:1 107 was used to track changes in the contribution of cyanobacteria due to its high concentration in many freshwater cyanobacteria (Sallal et al. 1990, Ahlgren et al. 1992). Individual PLFA concentrations were converted to nmols or $\mu \mathrm{mol} \mathrm{C}_{\mathrm{PLFA}}$ and used to calculate the flow of newly-fixed $\mathrm{C}$ into the total pool of $\mathrm{C}_{\text {PLFA }}$ $\left(\mathrm{C}_{\text {PLFA(newly-fixed) }}\right)$ and individual PLFAs extracted from the biofilms from each enclosure. The calculation of newly-fixed $\mathrm{C}$ into individual fatty acids during the course of incubation was used to follow autotrophic C through the microbial biofilm community. The quantity of $C_{\text {PLFA(newly-fixed) }}$ was determined by the change in $\delta^{13} \mathrm{C}_{\text {PLFA }}$ between the initial and final biofilm samples according to the following equations, which assume a negligible change in the total quantity of individual PLFAs in the biofilm community of each enclosure during the 7 to $9 \mathrm{~h}$ incubation:

$$
\begin{gathered}
F C_{\text {PLFA(newly-fixed) }}=\frac{\delta^{13} C_{\text {PLFA(final) }}-\delta^{13} C_{\text {PLFA(initial) }}}{\delta^{13} C_{\text {DIC(initial) }}-\delta^{13} C_{\text {PLFA(initial) }}} \\
\mathrm{C}_{\text {PLFA(newly-fixed) }}=F C_{\text {PLFA(newly-fixed) }} \times \mathrm{C}_{\text {PLFA }} \\
\mathrm{C}_{\text {PLFA(newly-fixed) }} \text { as \% of total } C_{\text {PLFA }}= \\
\frac{F C_{\text {PLFA(newly-fixed) }} \times C_{\text {PLFA }}}{C_{\text {PLFA }}} \times 100
\end{gathered}
$$

where $F C_{\text {PLFA(newly-fixed) }}$ is the fraction of $\mathrm{C}_{\text {PLFA }}$ (either total $\mathrm{C}_{\mathrm{PLFA}}$ or individual $\mathrm{C}_{\mathrm{PLFA}}$ ) derived from $\mathrm{C}$ fixed during the incubation, $\delta^{13} \mathrm{C}_{\text {PLFA(initial) }}$ and $\delta^{13} \mathrm{C}_{\text {PLFA(final) }}$ are the $\delta^{13} \mathrm{C}$ of the total (or individual) PLFAs at the start and end of the incubation, respectively, and $\mathrm{C}_{\mathrm{PLFA}}$ refers to the quantity of $\mathrm{C}(\mathrm{nmol}$ or $\mu \mathrm{mol} \mathrm{C})$ in the total biofilm PLFAs or individual PLFAs extracted from an individual enclosure. Newly-fixed $\mathrm{C}$ was determined using the equations above for the total biofilm $\mathrm{C}_{\text {PLFA, }}$ individual phototrophic $\mathrm{C}_{\text {PLFA }}(18: 3 \omega 3,20: 5 \omega 3,16: 1 \omega 7)$,

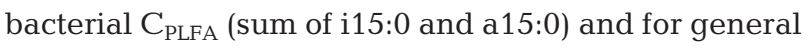
PLFA 16:0. Additionally, the sum of i15:0 and a15:0 relative to the sum of PUFAs was used as a relative measure of newly-fixed $\mathrm{C}$ incorporated by heterotrophic bacteria relative to $\mathrm{C}$ fixed by algae during the light enclosure incubations.

Analytical methods. DOC was measured by high temperature combustion and DIC was measured in $\mathrm{HgCl}_{2}$ preserved samples with a Shimadzu TOC 5050 carbon analyzer (Shimadzu Scientific Instruments). Concentrations of $\mathrm{NH}_{4}{ }^{+}$were determined using the phenol-hypochlorite method and $\mathrm{NO}_{3}{ }^{-}+\mathrm{NO}_{2}{ }^{-}$was determined using the standard cadmium reduction method modified for small samples. SRP was determined using the standard colorimetric method. Samples for $\delta^{13} \mathrm{C}_{\mathrm{DOC}}$ and $\delta^{13} \mathrm{C}_{\mathrm{DIC}}$ were analyzed at the Colorado Plateau Stable Isotope Laboratory at Northern Arizona University using an Aurora 1020 TOC analyzer (O.I. Analytical) coupled to a Delta Plus XL isotope ratio mass spectrometer (IRMS; Thermo Scientific). Biofilm samples were shell frozen and lyophilized before isotopic analysis. Biofilm $\% \mathrm{C}, \% \mathrm{~N}, \delta^{13} \mathrm{C}$ and $\delta^{15} \mathrm{~N}$ were determined at the University of Arkansas Stable Isotope Laboratory on a $2500 \mathrm{~N}$ elemental analyzer (Carlo Erba) interfaced with an IRMS via a Delta $a_{\text {plus }}$ Conflo II interface (Thermo Scientific) and standardized to peach leaf (NIST-1547) and 
acetanilide (Costech Analytical Technologies) standards. ${ }^{13} \mathrm{C}$ and ${ }^{15} \mathrm{~N}$ values are reported as $\delta$ values (\%) using the international reference standards Vienna PDB $(R=0.011237)$ and air $(R=0.0033676)$, respectively.

Statistical analysis. Paired $t$-tests were used to determine whether initial and final measurements, such as nutrient or DOC concentrations, from the enclosures were significantly different before using them in the net release or uptake calculations. Measurements of uptake rates of DIC from the enclosure incubations were further analyzed to test study stream and season effects on rates of net primary production (NPP), using a Generalized Linear Model (GLM [Lindsey 1997]; JMP 7.1, SAS) with the following equation:

$$
\begin{aligned}
& \text { NPP }\left(\mu \text { mol C mmol } \mathrm{C}_{\mathrm{BF}} \mathrm{h}^{-1}\right) \\
& \quad=\alpha+\text { season }+ \text { stream }+ \text { season } \times \text { stream }+\varepsilon
\end{aligned}
$$

where NPP refers to the rate of NPP measured as DIC uptake and stream refers to the study stream. Chisquare $\left(\chi^{2}\right)$ statistics from analysis of deviance within the framework of the GLM (Lindsey 1997) was used to declare significance. Signficance levels for all tests were $\alpha=5 \%$.

As expected from previous studies at these stream sites, NPP varied with stream site and season. Given this, and that (1) we expected NPP to be the main factor regulating the input of newly-fixed $\mathrm{C}$ into the pools studied, and (2) the limited number of factors that could be tested using these in situ enclosure incubations, season was not used as an explanatory factor when assessing variation in C flow rates. Since NPP and biofilm biomass were primary factors presumed to regulate $\mathrm{C}$ flow rates, such as net DOC release, analyses were conducted using total $\mathrm{C}$ released or incorporated (as $\mu \mathrm{mol}$ or $\mathrm{nmol} \mathrm{C}$ ) in each individual enclosure, rather than rates provided per unit biofilm biomass per unit time.

To assess how the proportion of total enclosure NPP retained within the epilithic biofilms varied between the 2 study streams (stream), a GLM with the following equation was used:

$$
\begin{aligned}
& \mathrm{C}_{\mathrm{BF} \text { (newly-fixed) }}(\mu \mathrm{mol} \mathrm{C}) \\
& \quad=\alpha+\mathrm{NPP}+\text { stream }+\mathrm{NPP} \times \text { stream }+\varepsilon
\end{aligned}
$$

where $\alpha$ and $\varepsilon$ are the constant and error terms, respectively. To determine whether nutrient and light availability further contributed to the variation in the newly-fixed C retained by the biofilm, a second GLM with the following equation was used:

$$
\begin{aligned}
& \mathrm{C}_{\mathrm{BF} \text { (newly-fixed) }}(\mu \mathrm{mol} \mathrm{C})=\alpha+\mathrm{NPP}+\text { stream } \\
& \quad+\mathrm{NPP} \times \text { stream }+\mathrm{DIN}+\mathrm{DIP}+\mathrm{L}+\mathrm{C}: \mathrm{N}_{\mathrm{BF}}+\varepsilon
\end{aligned}
$$

where DIN = stream water ammonium plus nitrate concentration, DIP $=$ stream water soluble reactive phosphate concentration, $\mathrm{C}: \mathrm{N}_{\mathrm{BF}}=$ biofilm $\mathrm{C}: \mathrm{N}$ ratio, and $\mathrm{L}=$ sum of UVA + UVB + PAR light measured at solar noon in $\mathrm{mW} \mathrm{m}^{-2}$. Because UVA, UVB and PAR were correlated, there was no way to distinguish between the influence of UV and PAR light level; therefore, total light was used to assess the influence of light availability in general. To avoid inflating the Type I error due to repeated testing, no tests were performed on the NPP, stream, or stream $\times$ NPP in the second set of GLM analyses (Hoffmann 2004). The influence of biofilm biomass $\left(\mathrm{C}_{\mathrm{BF}}\right)$ and NPP was presumed to be the most important factor regulating net release of $\mathrm{C}_{\mathrm{DOC}}$ from these biofilms. Therefore, to assess the influence of NPP and $\mathrm{C}_{\mathrm{BF}}$ on the net release of $\mathrm{C}_{\mathrm{DOC}}$ from biofilms in the light enclosures, a GLM with the following equation was used:

Net release of $\mathrm{C}_{\mathrm{DOC}}(\mu \mathrm{mol} \mathrm{C})$
$\quad=\alpha+\mathrm{NPP}+\mathrm{C}_{\mathrm{BF}}+\mathrm{NPP} \times \mathrm{C}_{\mathrm{BF}}+\varepsilon$

To determine whether the proportion of NPP released as DOC was different by site and whether that difference was driven by what we presumed to be key factors, we assessed the influence of stream site, nutrient and light availability on the net release of $\mathrm{C}_{\text {DOC }}$ as a proportion of NPP ( $\mu$ mol $\mathrm{C}$ : $\mu$ mol $\mathrm{C}$ ratio) in the light enclosure incubations using a GLM with the follow equation:

Net release of $\mathrm{C}_{\mathrm{DOC}}$ as a proportion of NPP

The present study was designed to assess the difference in C-flow between 2 contrasting streams where physiochemical attributes represented the range typical of the region. Therefore, to assess the influence of stream site and NPP on the distribution and flow of newly fixed carbon in the biofilms studied, a set of GLMs with the following equation was used:

$$
Y=\alpha+\mathrm{NPP}+\text { stream }+\mathrm{NPP} \times \text { stream }+\varepsilon
$$

where $Y$ is the response variable tested (each separately) for net release of newly-fixed $\mathrm{C}$ as DOC $\left(\mathrm{C}_{\text {DOC(newly-fixed) }}\right)$, newly-fixed $\mathrm{C}$ into $18: 3 \omega 3$ as relative measure of $\mathrm{C}$ flow into green algae $\left(\mathrm{C}_{\mathrm{GA} \text { (newly-fixed) }}\right)$, newly-fixed $C$ into $16: 1 \omega 7$ as relative measure of $C$ flow into cyanobacteria $\left(\mathrm{C}_{\mathrm{CY} \text { (newly-fixed) }}\right)$, newly-fixed $\mathrm{C}$ into ia15:0 as relative measure of $\mathrm{C}$ flow into heterotrophic bacteria $\left(\mathrm{C}_{\mathrm{HB} \text { (newly-fixed) }}\right)$, or the ratio of $\mathrm{C}_{\mathrm{HB} \text { (newly- }}$ fixed) to newly-fixed $\mathrm{C}$ into the sum of all PUFAs (i.e. $\mathrm{C}_{\mathrm{HB} \text { (newly-fixed) }} \mathrm{C}_{\text {PUFA(newly-fixed) }}$ ratio), which was used to assess the quantity of newly-fixed $\mathrm{C}$ in heterotrophic bacteria relative to algae in these biofilms. A second set of GLMs to assess the role of inorganic nutrient and light availability beyond any NPP or stream effect on these $\mathrm{C}$ flow measures with the following equation was used: 


$$
\begin{aligned}
Y & =\alpha+\mathrm{NPP}+\text { stream }+\mathrm{NPP} \times \text { stream }+\mathrm{DIN} \\
& +\mathrm{DIP}+\mathrm{C}: \mathrm{N}_{\mathrm{BF}}+\mathrm{L}+\mathrm{e}
\end{aligned}
$$

where $Y$, the response variable tested, was again $\mathrm{C}_{\mathrm{DoC}}$, $\mathrm{C}_{\mathrm{DOC} \text { (newly-fixed) }}, \mathrm{C}_{\mathrm{GA} \text { (newly-fixed) }}, \mathrm{C}_{\mathrm{CY} \text { (newly-fixed) }}, \mathrm{C}_{\mathrm{HB} \text { (newly- }}$ fixed) or $\mathrm{C}_{\mathrm{HB} \text { (newly-fixed) }} \mathrm{C}_{\text {PUFA(newly-fixed) }}$. To avoid inflating the Type I error, no p-values were calculated or tested on stream, NPP, or stream $\times$ NPP in the second set of GLMs (Hoffmann 2004).

The assumptions of homogeneous and normal errors for each GLM (Lindsey 1997) were checked by plotting residuals versus fits and by plotting residuals as probability plots. In cases where the violations were most evident a GLM entailing the same structural model but with a different error structure was used. The exponential error distribution was found to produce acceptable residuals in those cases where normal error assumptions were violated (Eqs. 11 \& 12; Eqs. 13 \& 14 applied only to response variables $\mathrm{C}_{\mathrm{GA} \text { (newly-fixed) }}$ and $\mathrm{C}_{\mathrm{HB} \text { (newly-fixed) }} \mathrm{C}_{\text {PUFA(newly-fixed) }) . \quad \text { Chi-square statistics }}$ from analysis of deviance within the framework of the GLM was used to declare significance. The exponential distribution is a special case of the gamma distribution and, like the gamma distribution, its effect is to reduce the weight given to observations exhibiting greater error (Lindsey 1997). In the few GLMs using the exponential error distribution, the deviance residual by predicted plot was assessed to determine whether the assumptions of the model were met before $\chi^{2}$ and p-values were calculated and used (Hoffmann 2004). All GLMs were calculated using JMP 7.1 (SAS). All analyses employed an alpha level of $5 \%$.

\section{RESULTS}

\section{Study site conditions}

Mean water temperatures during the incubation experiments ranged seasonally from a winter low of 6.8 and $9.0^{\circ} \mathrm{C}$ to a summer high of 20.8 and $21.9^{\circ} \mathrm{C}$ at the mid-reach study sites in Moore Creek and Huey Hollow, respectively. Stream water $\mathrm{pH}$ remained slightly alkaline at both study sites and ranged between 7.7 and 7.9. Concentrations of DO were highest in winter in both streams, but were lowest in the summer in Huey Hollow and during the spring sampling and experiment in Moore Creek (Table 1). Conductivity was generally 2 to 3 times higher at Moore Creek relative to Huey Hollow, partly due to greater nutrient and DOM concentrations. Surface UV and PAR light levels at Moore Creek were highest in summer and represented roughly 80 to $90 \%$ of open sky measurements made at solar noon throughout the year, probably due to the lack of a riparian zone and canopy cover. Highest light levels were found in spring at the Huey Hollow site (Table 1), where canopy cover was extensive in summer and where surface site measurements ranged from 15 to $90 \%$ of open sky measurements throughout the year.

Dissolved inorganic nitrogen (DIN) concentrations were generally higher at Moore Creek than at Huey Hollow (Table 1). Highest levels at Moore Creek were observed in winter, probably reflecting lower productivity levels at that time. Summer DIN levels, however, were lower at Moore Creek, probably due to higher N demand. Biofilms in this stream supported higher rates of primary production (Table 2), probably supported by much higher light and $\mathrm{P}$ availability. In contrast to DIN concentrations, SRP was consistently higher in Moore Creek, particularly in spring when fertilizer application and runoff is greatest in the region (Table 1). DOC concentrations were typically 10-fold higher at Moore Creek and ranged from 284 to $644 \mu \mathrm{M}$, compared with 19 to $80 \mu \mathrm{M}$ in Huey Hollow (Table 1). These values are similar to those measured in previous studies of these streams (Brisco \& Ziegler 2004, Ziegler \& Brisco 2004). In both streams, DOC concentrations were highest in spring and summer. The $\delta^{13} C_{\text {DOC }}$ ranged from -25.6 to $-24.7 \%$ at Moore Creek and from -28.2 to $-27.0 \%$ at Huey Hollow, congruent with more algal sources of DOC in Moore

Table 1. Environmental variables at Moore Creek and Huey Hollow. Average water temperature (T), dissolved oxygen (DO), conductivity (Cond), dissolved inorganic nitrogen ( $\mathrm{DIN} \pm \mathrm{SD}$; sum of nitrate-, nitrite-, and ammonium-nitrogen), soluble reactive phosphorus (SRP $\pm \mathrm{SD}$ ), dissolved organic carbon (DOC $\pm \mathrm{SD}$ ), irradiance of ultraviolet light as UVA (320-400 nm) and

\begin{tabular}{|c|c|c|c|c|c|c|c|c|c|c|}
\hline Site & & $\begin{array}{c}\mathrm{T} \\
\left({ }^{\circ} \mathrm{C}\right)\end{array}$ & $\begin{array}{c}\mathrm{DO} \\
\left(\mathrm{mg} \mathrm{l}^{-1}\right)\end{array}$ & $\begin{array}{l}\text { Cond } \\
(\mu \mathrm{S})\end{array}$ & $\begin{array}{l}\text { DIN } \\
(\mu \mathrm{M})\end{array}$ & $\begin{array}{l}\text { SRP } \\
(\mu \mathrm{M})\end{array}$ & $\begin{array}{l}\text { DOC } \\
(\mu \mathrm{M})\end{array}$ & $\begin{array}{c}\text { UVA } \\
\left(\mathrm{mW} \mathrm{m}^{-2}\right)\end{array}$ & $\begin{array}{c}\text { UVB } \\
\left(\mu \mathrm{W} \mathrm{m}^{-2}\right)\end{array}$ & $\begin{array}{c}\text { PAR } \\
\left(\mathrm{mW} \mathrm{m}^{-2}\right)\end{array}$ \\
\hline Moore & Winter & 6.8 & 9.5 & 157.4 & $24.3 \pm 2$ & $8.7 \pm 1.1$ & $284 \pm 7$ & 1.6 & 10.5 & 23.2 \\
\hline \multirow[t]{2}{*}{ Creek } & Spring & 15.2 & 4.7 & 177.1 & $3.0 \pm 0.5$ & $11.5 \pm 0.3$ & $644 \pm 4$ & 2.6 & 63.0 & 35.8 \\
\hline & Summer & 20.8 & 6.5 & 189.5 & $1.3 \pm 0.2$ & $1.2 \pm 0.1$ & $613 \pm 5$ & 3.9 & 72.2 & 39.3 \\
\hline Huey & Winter & 9.0 & 8.6 & 27.5 & $3.5 \pm 0.3$ & $0.3 \pm 0.01$ & $19 \pm 1$ & 1.0 & 12.8 & 11.1 \\
\hline \multirow[t]{2}{*}{ Hollow } & Spring & 13.7 & 7.2 & 53.4 & $1.5 \pm 0.3$ & $0.3 \pm 0.04$ & $61 \pm 4$ & 1.4 & 21.9 & 22.2 \\
\hline & Summer & 21.9 & 5.1 & 70.2 & $3.6 \pm 0.7$ & $0.3 \pm 0.03$ & $80 \pm 3$ & 0.9 & 23.3 & 17.1 \\
\hline
\end{tabular}
UVB (280-320 nm), and photosynthetically active radiation (PAR) measured within $1 \mathrm{~h}$ of solar noon at the enclosure surface 
Table 2. Light enclosure incubations conducted at the 2 study streams during all 3 seasons. Epilithic biofilm molar C:N ratio

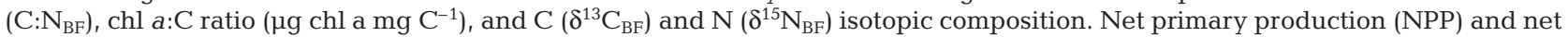

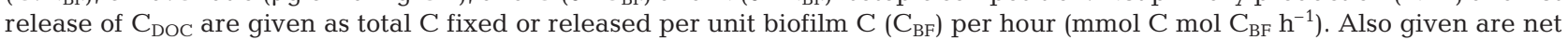
release of $\mathrm{C}_{\mathrm{DOC}}$ as $\%$ of NPP and $\%$ net $\mathrm{C}_{\mathrm{DOC}}$ release derived from newly-fixed $\mathrm{C}$. All values are mean $\pm \mathrm{SD}(\mathrm{n}=6$ for all biofilm characteristics, $\mathrm{n}=3$ for light enclosure rate measurements)

\begin{tabular}{|c|c|c|c|c|c|c|c|c|}
\hline Site & $C: N_{B F}$ & $\begin{array}{l}\text { Biofilm } \\
\text { chl } a: C\end{array}$ & $\begin{array}{c}\delta^{13} \mathrm{C}_{\mathrm{BF}} \\
\%\end{array}$ & $\begin{array}{c}\delta^{15} \mathrm{~N}_{\mathrm{BF}} \\
\% o\end{array}$ & NPP & $\begin{array}{l}\text { Net } \\
\text { release } \\
\text { of } \mathrm{C}_{\mathrm{DOC}}\end{array}$ & $\begin{array}{c}\text { Net release } \\
\text { of } \mathrm{C}_{\mathrm{DOC}} \text { as } \\
\% \text { of NPP }\end{array}$ & $\begin{array}{c}\% \mathrm{C}_{\mathrm{DOC}} \\
\text { derived from } \\
\text { newly-fixed C }\end{array}$ \\
\hline \multicolumn{9}{|c|}{ Moore Creek } \\
\hline Winter & $7.4 \pm 0.2$ & $22.2 \pm 4$ & $-21.9 \pm 0.2$ & $5.9 \pm 0.4$ & $4.0 \pm 0.4$ & $1.1 \pm 0.3$ & $27 \pm 11$ & $6.5 \pm 1.2$ \\
\hline Spring & $7.1 \pm 0.7$ & $10.8 \pm 1$ & $-25.6 \pm 0.8$ & $8.2 \pm 0.3$ & $8.3 \pm 0.7$ & $0.7 \pm 0.0$ & $8 \pm 0.2$ & $5.5 \pm 0.5$ \\
\hline Summer & $9.3 \pm 0.6$ & $6.7 \pm 2$ & $-19.3 \pm 1.0$ & $7.5 \pm 0.6$ & $11.3 \pm 0.7$ & $3.0 \pm 0.0$ & $27 \pm 1.4$ & $14.9 \pm 6.8$ \\
\hline \multicolumn{9}{|c|}{ Huey Hollow } \\
\hline Winter & $8.4 \pm 0.8$ & $8.2 \pm 0.3$ & $-22.7 \pm 0.3$ & $-1.0 \pm 0.6$ & $3.2 \pm 0.7$ & $0.7 \pm 0.0$ & $23 \pm 6$ & $0.7 \pm 0.1$ \\
\hline Spring & $10.4 \pm 0.3$ & NA & $-22.3 \pm 0.8$ & $-0.5 \pm 0.9$ & $1.2 \pm 0.3$ & $0.5 \pm 0.1$ & $45 \pm 7$ & $0.7 \pm 0.5$ \\
\hline Summer & $8.4 \pm 0.4$ & $5.4 \pm 0.8$ & $-24.8 \pm 0.6$ & $-0.9 \pm 0.4$ & $5.6 \pm 0.7$ & $1.0 \pm 0.2$ & $18 \pm 7$ & $1.9 \pm 0.8$ \\
\hline
\end{tabular}

Creek relative to Huey Hollow as found in a previous study (Ziegler \& Brisco 2004).

The molar $\mathrm{C}: \mathrm{N}_{\mathrm{BF}}$ ranged from 7.1 to 9.3 in Moore Creek and from 8.4 to 10.4 in Huey Hollow, with lower ratios found in Moore Creek in winter and spring (Table 2). The chlorophyll a (chl a):C ratio was higher in Moore Creek, where it ranged from 6.7 (summer) to 22.2 (winter), compared with 5.4 (summer) and 8.2 (winter) in Huey Hollow (Table 2). The chl a:C ratio was more variable in the Moore Creek biofilm samples. The $\delta^{13} \mathrm{C}$ of the biofilm also varied seasonally in Moore Creek, ranging from -25.6 to $-19.3 \%$, in contrast to the relatively stable range of -24.8 to $-22.3 \%$ in Huey Hollow (Table 2). The $\delta^{15} \mathrm{~N}$ of the biofilms from the 2 sites ranged from 5.9 to $8.2 \%$ in Moore Creek and from -1.0 to $-0.5 \%$ in Huey Hollow, indicating the greater contribution of manure to $\mathrm{N}$ in Moore Creek (Table 2).

\section{NPP and respiration in enclosures}

Biofilm community NPP was estimated from the uptake of DIC normalized to total $\mathrm{C}_{\mathrm{BF}}$ in the light enclosure incubations. Changes in DO in the light enclosures were not used to estimate NPP because midday DO levels were often at saturating levels and the presence of bubbles on the substrate suggested production of $\mathrm{O}_{2}$ not accounted for in our measurements during the spring and summer incubations. In the dark enclosure incubations, however, changes in DO were used to estimate community respiration (R) because DO levels remained below saturation throughout the incubation. Significant changes in DO (as opposed to DIC) remained linear during the dark incubation periods. Light and dark BOD bottles were also incubated in situ to estimate the contribution of stream water metabolism to the enclosure estimates. Changes in DO in the light bottle incubations were only significant at Moore Creek during the summer, and, when scaled up to the volume of stream water in each of the enclosures, the stream water NPP represented $0.05 \%$ of the total enclosure NPP (data not shown).

The rate of NPP in the light enclosures varied from 22 to $101 \mu \mathrm{M} \mathrm{C} \mathrm{h}^{-1}$ in Moore Creek and from 11 to $21 \mathrm{\mu M} \mathrm{C} \mathrm{h}^{-1}$ in Huey Hollow. $\mathrm{C}_{\mathrm{BF}}$-normalized NPP varied significantly with site $\left(\chi_{1,12}^{2}=22.22, p<0.0001\right)$, season $\left(\chi_{2,12}^{2}=28.11, \mathrm{p}<0.0001\right)$, and site $\times$ season $\left(\chi_{2,12}^{2}=13.21, p<0.0014\right)$, with highest values in Moore Creek ranging from 4.0 in winter to $11.3 \mathrm{mmol}$ $\mathrm{C}$ mol $\mathrm{C}_{\mathrm{BF}}{ }^{-1} \mathrm{~h}^{-1}$ in summer, and lowest values in Huey Hollow ranging from 1.2 in spring to $5.6 \mathrm{mmol} \mathrm{C} \mathrm{mol}$ $\mathrm{C}_{\mathrm{BF}}{ }^{-1} \mathrm{~h}^{-1}$ in summer (Table 2). We estimated NPP on an aerial basis, assuming that Moore Creek and Huey Hollow had average periphyton biomasses of $3 \mathrm{~g} \mathrm{~m}^{-2}$ as reported for other Ozark streams (Petersen \& Femmer 2002). Applying the $\mathrm{C}_{\mathrm{BF}}$ from the enclosure incubations, these estimates of NPP ranged from 0.4 to 1.0 $\mathrm{mmol} \mathrm{C} \mathrm{m}{ }^{-2} \mathrm{~h}^{-1}$ in Moore Creek and 0.1 to $0.7 \mathrm{mmol} \mathrm{C}$ $\mathrm{m}^{-2} \mathrm{~h}^{-1}$ in Huey Hollow and are within the range reported for other headwater streams of the southern USA (Webster et al. 1983).

Net production of DIC was not significant in any of the dark enclosure incubations, probably due to small changes relative to a large DIC background concentration and, perhaps, simultaneous chemoautotrophy. However, DO consumption in the dark enclosure incubations was significant in summer in Moore Creek $\left(1.2 \pm 0.4 \mathrm{mmol} \mathrm{C} \mathrm{mol} \mathrm{C}_{\mathrm{BF}}{ }^{-1} \mathrm{~h}^{-1}\right.$, mean $\left.\pm \mathrm{SD}\right)$ as well as in spring $\left(0.2 \pm 0.08 \mathrm{mmol} \mathrm{C} \mathrm{mol} \mathrm{C}_{\mathrm{BF}^{-1}} \mathrm{~h}^{-1}\right)$ and summer $\left(2.0 \pm 0.8 \mathrm{mmol} \mathrm{C} \mathrm{mol} \mathrm{C}_{\mathrm{BF}}{ }^{-1} \mathrm{~h}^{-1}\right)$ in Huey Hollow, suggesting that biofilm heterotrophic activities were greatest in summer at both sites. Additionally, these data suggest that the Huey Hollow biofilms were prob- 
ably more heterotrophic than those at Moore Creek. Stream water community respiration rates, measured as DO consumption in dark BOD bottles, were all below the level of detection, except in summer at both Moore Creek and Huey Hollow, when rates, scaled up to the enclosure volumes, represented $0.3 \%$ and $0.1 \%$ of dark enclosure R for Moore Creek and Huey Hollow, respectively (data not shown).

\section{Net nutrient release and uptake rates}

Significant net changes in DIN or SRP concentrations over the course of the incubation were not detected in most enclosures. In Moore Creek, net release of SRP (15.2 $\mu \mathrm{mol} \mathrm{P} \mathrm{mol} \mathrm{C}_{\mathrm{BF}}{ }^{-1} \mathrm{~h}^{-1}$ ) occurred in the light incubations in summer. Net uptake of ammonium occurred in the dark incubations in summer $(-6.7 \mu \mathrm{mol} \mathrm{N}$ mol $\mathrm{C}_{\mathrm{BF}}{ }^{-1} \mathrm{~h}^{-1}$ ), net uptake of nitrate occurred in the light in spring $\left(-12.1 \mu \mathrm{mol} \mathrm{N}\right.$ mol $\left.\mathrm{C}_{\mathrm{BF}}{ }^{-1} \mathrm{~h}^{-1}\right)$ and in the dark in summer $\left(-2.1 \mu \mathrm{mol} \mathrm{N}\right.$ mol $\left.\mathrm{C}_{\mathrm{BF}}{ }^{-1} \mathrm{~h}^{-1}\right)$, while net uptake of SRP occurred only in the dark during the spring and summer in Moore Creek. In Huey Hollow, nutrient uptake-release rates were dominated by net ammonium uptake, which ranged from -4.2 in spring to $-31.7 \mu \mathrm{mol} \mathrm{N}$ mol $\mathrm{C}_{\mathrm{BF}}{ }^{-1} \mathrm{~h}^{-1}$ in summer, following the trend in NPP in the light enclosures. Similar but lower net ammonium uptake rates were observed in the dark incubations in spring $\left(-2.2 \mu \mathrm{mol} \mathrm{N}\right.$ mol $\left.\mathrm{C}_{\mathrm{BF}}{ }^{-1} \mathrm{~h}^{-1}\right)$ and summer $\left(-21 \mu \mathrm{mol} \mathrm{N}\right.$ mol $\left.\mathrm{C}_{\mathrm{BF}}{ }^{-1} \mathrm{~h}^{-1}\right)$ in Huey Hollow, congruent with differences in $\mathrm{R}$ measured at those times. Net uptake of SRP in Huey Hollow, however, only occurred in the dark in winter $(-5.0 \mu \mathrm{mol} \mathrm{P}$ mol $\left.\mathrm{C}_{\mathrm{BF}}{ }^{-1} \mathrm{~h}^{-1}\right)$ and summer $\left(-1.5 \mu \mathrm{mol} \mathrm{P}\right.$ mol $\left.\mathrm{C}_{\mathrm{BF}}{ }^{-1} \mathrm{~h}^{-1}\right)$.

\section{Dissolved organic carbon release and ${ }^{13} \mathrm{C}$-labeling}

Net release of DOC into the stream water occurred in all light enclosure incubations. Since net changes in DOC concentrations within the dark enclosures were not significant (all p-values $>0.1$ ), these data were not used or reported further. In Moore Creek, the net DOC release exhibited a wider range from 6.3 to $21.8 \mu \mathrm{M} \mathrm{C}$ $\mathrm{h}^{-1}$, while it ranged from 3.6 to $5.0 \mu \mathrm{M} \mathrm{C} \mathrm{h}{ }^{-1}$ in Huey Hollow. We assume that the net release of DOC from stream water particulate organic matter was minimal relative to the biofilm source, given the small fraction of NPP measured in the stream water used in these enclosure incubations. Biofilm-normalized values of the net DOC release rates were more similar among seasons and between the 2 sites (Table 2). NPP was the only variable in the first GLM that exhibited a significant effect on total net DOC release in $\mu \mathrm{mol} \mathrm{C}\left(\chi^{2}{ }_{1,14}=\right.$ 9.2574, $p=0.0157$; Fig. 1$)$, while $\mathrm{C}_{\mathrm{BF}}(\mathrm{p}=0.8060), \mathrm{C}_{\mathrm{BF}} \times$

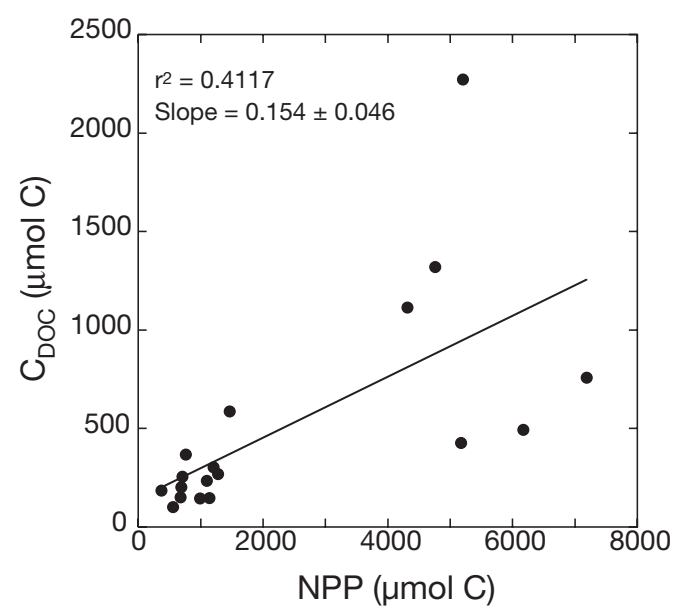

Fig. 1. Net dissolved organic carbon (DOC) release versus primary production (NPP) for all light enclosure incubations conducted at both Moore Creek and Huey Hollow. NPP was the only factor in the Generalized Linear Model (GLM) that exhibited a significant effect $\left(\chi_{1,14}^{2}=9.26, p=0.0157\right)$ on net DOC release in the light enclosure incubations. The quantity of NPP and net DOC release is provided as total C for the entire enclosure volume and incubation period. Solid line represents the results of the least squares regression; slope and $\mathrm{r}^{2}$ values are reported

NPP ( $p=0.5395)$, the effects of stream site $(p=0.8507)$, $C: N_{B F}(p=0.9395), D I N(p=0.7671), D I P(p=0.3557)$ and light $(p=0.8678)$ did not exhibit any significant effect on net DOC release. The net release of DOC in the light incubations represented between 8 and $27 \%$ of NPP and 18 and $45 \%$ of NPP at Moore Creek and Huey Hollow, respectively (Table 2). Net DOC release as a proportion of NPP varied significantly with stream site $\left(\chi_{1,12}^{2}=10.7359, \mathrm{p}=0.0051\right)$, stream water DIN $\left(\chi_{1,12}^{2}=12.7912, \mathrm{p}=0.003\right)$, DIP $\left(\chi_{1,12}^{2}=12.2677, \mathrm{p}=\right.$ $0.0005)$ and surface light $\left(\chi_{1,12}^{2}=12.2691, p=0.0005\right)$, suggesting that these factors contributed to the site differences such that net DOC release as a proportion of NPP decreased with increasing DIN and increased with light level in Huey Hollow while it decreased with increasing DIP in Moore Creek (Fig. 2). C: $\mathrm{N}_{\mathrm{BF}}(\mathrm{p}=$ 0.0545), however, did not exhibit a significant effect on net DOC release as a proportion of NPP in the second GLM. The released quantity of $\mathrm{C}_{\mathrm{DOC} \text { (newly-fixed), as }}$ determined from ${ }^{13} \mathrm{C}$-labeling of the DOC, varied significantly with site $\left(\chi_{1,14}^{2}=12.9041, \mathrm{p}=0.0003\right)$, ranging from 5.5 to $14.9 \%$ of the net DOC flux in Moore Creek compared to a range from 0.7 to $1.9 \%$ in Huey Hollow (Table 2). The quantity of $\mathrm{C}_{\mathrm{DOC}(\text { newly-fixed) }}$ also varied significantly with DIP $\left(\chi_{1,9}^{2}=18.2524, \mathrm{p}<\right.$ $0.0001)$ with decreasing quantities of $\mathrm{C}_{\text {DoC(newly-fixed) }}$ with increasing DIP in Moore Creek (Fig. 3), while $C: \mathrm{N}_{\mathrm{BF}}(\mathrm{p}=0.3217)$, DIN ( $\left.\mathrm{p}=0.2554\right)$, and light $(\mathrm{p}=$ 0.9224 ) exhibited no significant effect in the GLM for the quantity of $\mathrm{C}_{\mathrm{DOC} \text { (newly-fixed) }}$ released. 

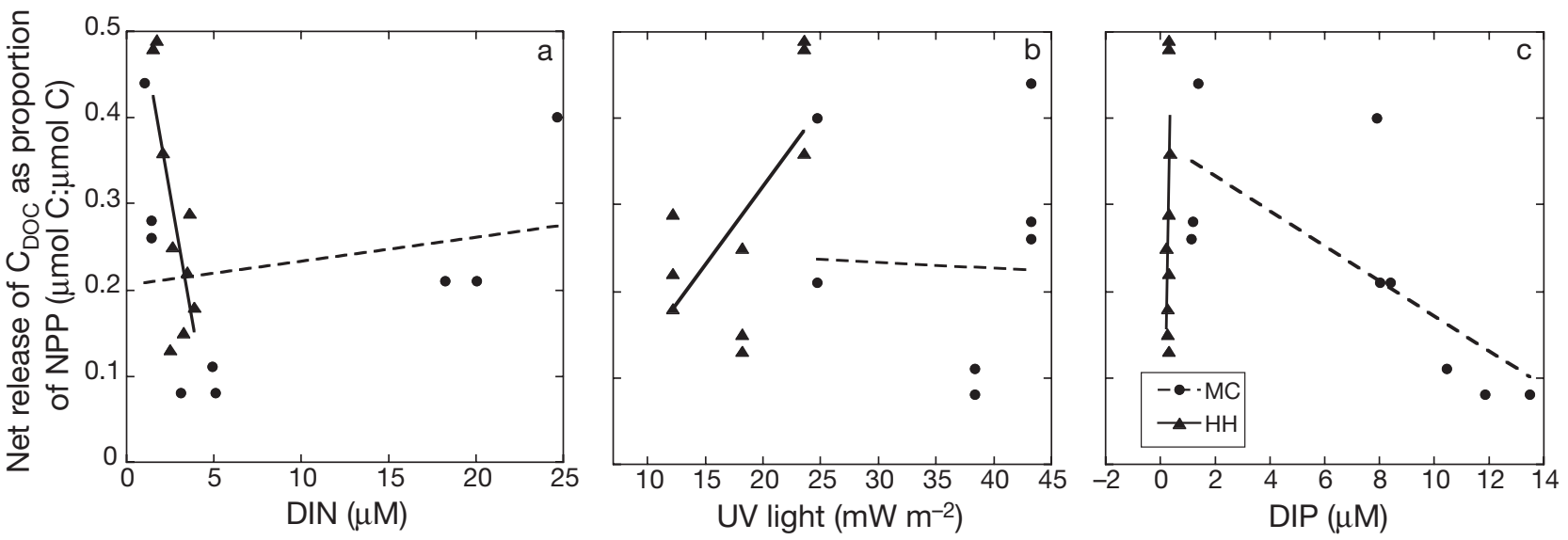

Fig. 2. Net release of dissolved organic carbon (DOC) as a proportion of net primary production (NPP) versus (a) dissolved inorganic nitrogen (DIN), (b) total surface light (sum of UVA + UVB + PAR), and (c) dissolved inorganic phosphate (DIP) at Moore Creek (MC) and Huey Hollow (HH). Net release of DOC as a proportion of NPP varied significantly, as determined by GLM, with stream site $\left(\chi_{1,12}^{2}=10.74, p=0.0051\right)$, stream water DIN $\left(\chi_{1,12}^{2}=12.79, p=0.003\right)$, DIP $\left(\chi_{1,12}^{2}=12.26, p=0.0005\right)$ and surface light $\left(\chi_{1,12}^{2}=12.27, p=0.0005\right)$. Net DOC release as a proportion of NPP decreased with increasing DIN and increased with light level in $\mathrm{HH}(\boldsymbol{\Delta})$ while it decreased with increasing DIP in $\mathrm{MC}(\bullet)$. Lines represent the least squares regression results for MC (- - ) and $\mathrm{HH}(-)$

\section{Biofilm PLFA composition and ${ }^{13} \mathrm{C}-$-labeling}

Bulk biofilm was enriched with ${ }^{13} \mathrm{C}$ following the in situ incubations of the light enclosures while the $\delta^{13} \mathrm{C}$ of bulk biofilm following the dark incubations were not significantly different from the initial $\delta^{13} \mathrm{C}$ values. The variation in $\mathrm{C}_{\mathrm{BF} \text { (newly-fixed) }}$ was significantly influenced by NPP $\left(\chi_{1,14}^{2}=30.3954, \mathrm{p}<0.0001 ; \mathrm{mmol} \mathrm{C}\right)$, as expected, and by DIP $\left(\chi_{1,9}^{2}=11.0384, \mathrm{p}=0.0094\right)$ such that greater retention of $\mathrm{C}_{\mathrm{BF} \text { (newly-fixed) occurred }}$ with increasing DIP. Stream site $(p=0.7088), C: \mathrm{N}_{\mathrm{BF}}$ $(p=0.7371)$, DIN $(p=0.2335)$ and light $(p=0.3039)$, however, did not exhibit significant effects on $\mathrm{C}_{\mathrm{BF} \text { (newly-fixed) }}$ in the 2 GLMs used. The least squares regression of $\mathrm{C}_{\mathrm{BF} \text { (newly-fixed) }}$ versus NPP exhibited an $\mathrm{r}^{2}$ $=0.878$ and slope $=0.66$. This suggested that net uptake of new $\mathrm{C}$ into these biofilms represented roughly $66 \%$ of total enclosure NPP over the course of the study. However, the sum of the $\mathrm{C}_{\mathrm{BF} \text { (newly-fixed) }}$ and $\mathrm{C}_{\mathrm{DOC} \text { (newly-fixed) }}$ following the light enclosure incubations ranged between 50 and $97 \%$ of NPP as measured by DIC uptake in the light enclosures, suggesting losses of fixed $\mathrm{C}$ during sample processing. The most likely loss was in the recovery of the epilithic biofilms following the incubations. Loosely associated or colloidal components of the biofilm would have been lost from our collections since all substrates were rinsed thoroughly with ambient, unlabeled stream water on site before being scrubbed to collect the attached biofilms. Additionally, some biofilm components may have remained embedded in the minerals of the rock substrate. Due to these potential

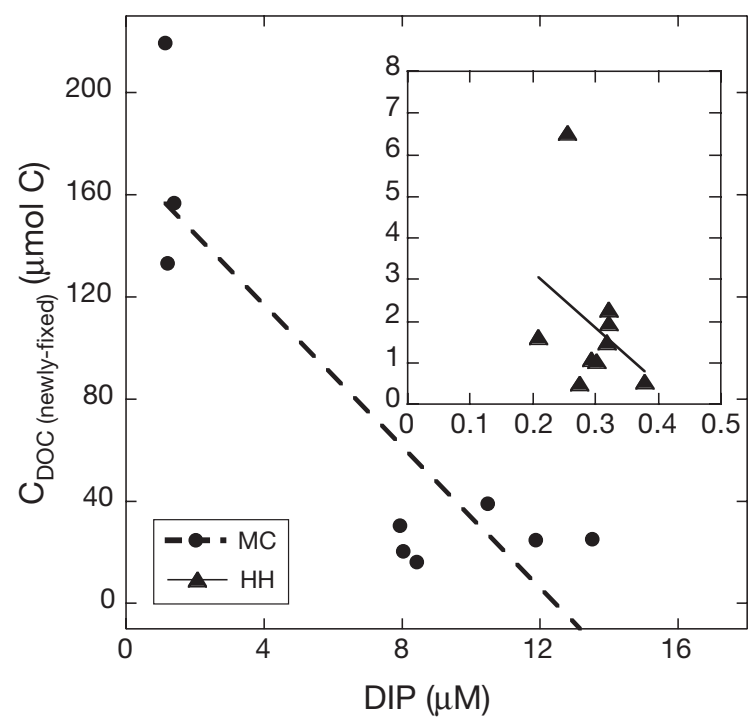

Fig. 3. Newly-fixed $\mathrm{C}$ released as dissolved organic carbon (DOC) $\left(\mathrm{C}_{\mathrm{DOC} \text { (newly-fixed) }}\right)$ following the light incubation period versus dissolved inorganic phosphate (DIP), plotted separately for Moore Creek (MC) and Huey Hollow (HH). The quantity of $\left(\mathrm{C}_{\mathrm{DOC} \text { (newly-fixed) }}\right)$ exhibited a significant effect, as determined by GLM, with stream site $\left(\chi_{1,14}^{2}=12.9041, \mathrm{p}=\right.$ $0.0003)$ and $\operatorname{DIP}\left(\chi_{1,9}^{2}=18.2524, p<0.0001\right)$, with decreasing quantities of $\left(\mathrm{C}_{\mathrm{DOC}(\text { newly-fixed) }}\right)$ with increasing DIP in $\mathrm{MC},(\bullet)$, but not in $\mathrm{HH}_{1}(\boldsymbol{\Delta})$. Lines represent the least squares regression results for $\mathrm{MC} \mathrm{(-} \mathrm{-} \mathrm{-)} \mathrm{and} \mathrm{HH}(-)$

losses, results are related to NPP measured as the net uptake of DIC, as opposed to $\mathrm{C}$ fixed into biofilm and DOC as determined from the ${ }^{13} \mathrm{C}$-labeling following the light incubations. 
There were 39 individual PLFAs detected and identified from the biofilm samples. The most abundant PLFAs were 16:0 and 16:1 107 , with 16:0 ranging up to $54.3 \%$ (weight \% of total PLFAs) in Moore Creek and $40.2 \%$ in Huey Hollow, and 16:1 $\omega 7$ reaching $26.3 \%$ in Moore Creek and $15.8 \%$ in Huey Hollow. These maximum values were attained during the winter. The other most common PLFAs at both sites were 18:1 19 , $18: 1 \omega 7,18: 2 \omega 6$ and $18: 3 \omega 3$, all of which ranged up to between 10.7 and $13.5 \%$. Other PLFAs detected at or

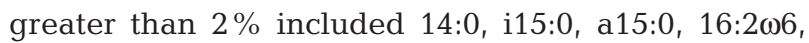

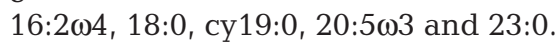

We determined the quantity of newly-fixed $\mathrm{C}$ in each individual PLFA to assess the relative activity of autotrophic groups and the use of newly-fixed $\mathrm{C}$ by bacteria in the biofilms. The quantity of newly-fixed $\mathrm{C}$ into the ubiquitous PLFA 16:0 exhibited a stream site $\left(\chi_{1,14}^{2}=7.2883, \mathrm{p}=0.0069\right), \mathrm{NPP}\left(\chi_{1,14}^{2}=13.5080, \mathrm{p}=\right.$ $0.0002)$ and stream site $\times \operatorname{NPP}\left(\chi_{1,14}^{2}=5.8077, \mathrm{p}=\right.$ 0.0160 ) effect, indicating that newly-fixed $C$ in biofilm PLFAs as a proportion of NPP was greater in Huey Hollow compared to Moore Creek (Fig. 4). Further, newlyfixed $C$ into the PLFA 16:0 exhibited a DIP effect $\left(\chi_{1,9}^{2}=21.4022, p=0.0005\right)$ such that greater newlyfixed $\mathrm{C}$ in 16:0 occurred with increased concentration of DIP. The effects of C: $\mathrm{N}_{\mathrm{BF}}(\mathrm{p}=0.5106)$, DIN ( $\mathrm{p}=$ $0.4749)$ or light $(p=0.2867)$ on newly-fixed $C$ into the PLFA 16:0, however, were not significant. The quantity of newly-fixed $\mathrm{C}$ in 18:3 $\omega 3$ exhibited an effect with stream site such that it was significantly greater in Moore Creek compared to Huey Hollow $\left(\chi_{1,14}^{2}=\right.$ 7.5330, $\mathrm{p}=0.0262)$, but exhibited no $\mathrm{C}: \mathrm{N}_{\mathrm{BF}}(\mathrm{p}=$ $0.5201)$, DIN $(p=5490)$, DIP $(p=0.9412)$ or light $(p=$ 0.0917 ) effect, making it difficult to assess the physiochemical factors that probably contributed to the difference between the 2 study streams. The $\delta^{13} \mathrm{C}$ of diatom PLFA 20:5 13 was only resolved in the Moore Creek incubations because concentrations were too low in the Huey Hollow samples. Newly-fixed $\mathrm{C}$ in $16: 1 \omega 7\left(\mathrm{C}_{\mathrm{CY}(\text { newly-fixed) }}\right)$, common in cyanobacteria, did not exhibit any stream $(p=0.3749)$ or NPP $(p=0.2795)$ effects, nor DIN ( $p=0.7433), C: N_{B F}(p=0.1237)$ or light $(p=0.6936)$ effects, but did vary significantly with DIP $\left(\chi_{1,9}^{2}=22.6456, p=0.0004 ;\right.$ Fig. 5$)$ such that $\mathrm{C}_{\mathrm{CY} \text { (newly- }}$ fixed) increased with DIP. Newly-fixed $\mathrm{C}$ in the bacterial PLFA ia15:0 ( $\left.\mathrm{C}_{\mathrm{HB} \text { (newly-fixed) }}\right)$ exhibited a significant stream site $\left(\chi_{1,14}^{2}=14.5628, \mathrm{p}=0.0035\right)$, NPP $\left(\chi_{1,14}^{2}=\right.$ $15.5028, \mathrm{p}=0.0027)$ and stream site $\times \operatorname{NPP}\left(\chi_{1,14}^{2}=\right.$ 9.7946, $\mathrm{p}=0.0135$ ) effect, where the quantity of $\mathrm{C}_{\mathrm{HB}(\text { newly-fixed) }}$ relative to NPP in Huey Hollow was about 4 times higher compared with Moore Creek (Fig. 6a). Further, $\mathrm{C}_{\mathrm{HB}(\text { newly-fixed) }}$ exhibited a significant DIP $\left(\chi_{1,9}^{2}=10.3776, p=0.0113\right)$ effect, such that greater $\mathrm{C}_{\mathrm{HB}(\text { newly-fixed) }}$ occurred with higher DIP concentrations. However, $C: N_{B F}(p=0.2957), D I N(p=0.0534)$ and

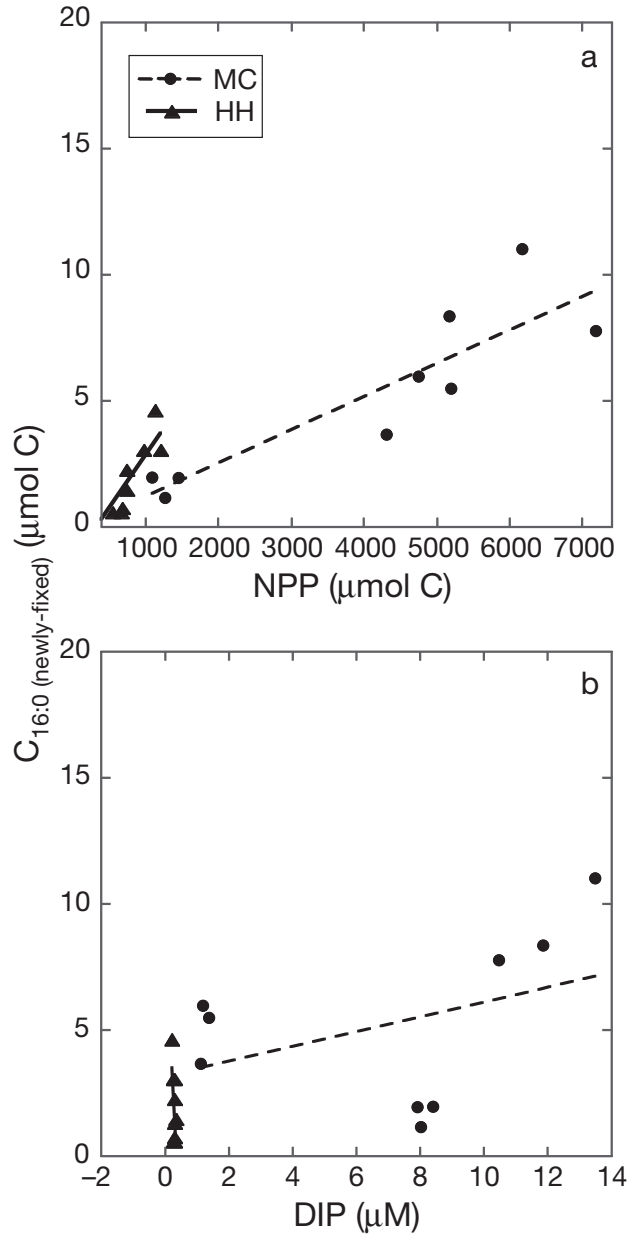

Fig. 4. Quantity of newly-fixed C in PLFA 16:0 ( $\left.\mathrm{C}_{16: 0 \text { (newly-fixed) }}\right)$ following the light incubations versus (a) net primary production (NPP) and (b) dissolved inorganic phosphate (DIP). $\mathrm{C}_{16: 0(\text { newly-fixed) }}$ exhibited a significant stream site $\left(\chi_{1,14}^{2}=\right.$ $7.2883, p=0.0069), \operatorname{NPP}\left(\chi_{1,14}^{2}=13.5080, \mathrm{p}=0.0002\right)$ and stream site $\times \operatorname{NPP}\left(\chi_{1,14}^{2}=5.8077, \mathrm{p}=0.0160\right)$ effect, as determined by GLM, indicating that $\mathrm{C}_{16: 0 \text { (newly-fixed) }}$ as a proportion of NPP was greater in Huey Hollow $(\mathrm{HH}, \mathbf{\Delta})$ relative to Moore Creek $(\mathrm{MC}, \bullet)$. Further, $\mathrm{C}_{16: 0 \text { (newly-fixed) }}$ exhibited a DIP effect $\left(\chi^{2}{ }_{1,9}=21.4022, p=0.0005\right)$ such that it increased with increasing concentration of DIP. Lines represent the least squares regression results for $\mathrm{MC}(--)^{-}$and $\mathrm{HH}(-)$

light $(p=0.4171)$ did not exhibit significant effects on $\mathrm{C}_{\mathrm{HB}(\text { newly-fixed) }}$ The proportion of $\mathrm{C}_{\mathrm{HB} \text { (newly-fixed) }}$ relative to PUFAs, as an indicator of the proportion of new $\mathrm{C}$ in heterotrophic bacteria relative to algae, exhibited a significant stream site $\left(\chi_{1,14}^{2}=10.9788, \mathrm{p}=0.00955\right)$, NPP $\left(\chi_{1,14}^{2}=7.1351, \mathrm{p}=0.02945\right)$, and stream site $\times$ NPP $\left(\chi_{1,14}^{2}=6.8644, p=0.03195\right)$ effect (Fig. 6b). The lack of a significant effect of $C: \mathrm{N}_{\mathrm{BF}}(\mathrm{p}=0.9208)$, DIN $(p=0.7651)$, DIP $(p=0.8634)$ or light $(p=0.9013)$ made it difficult to attribute the differences in $\mathrm{C}_{\mathrm{HB} \text { (newly- }}$ fixed) $C_{\text {PLFA(newly-fixed) }}$ observed between the 2 study sites to any specific physiochemical factors. 


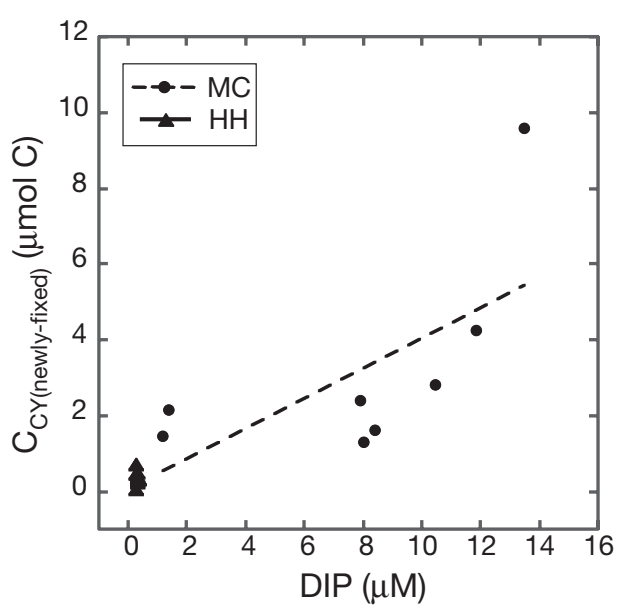

Fig. 5. Quantity of newly-fixed C in PLFA 16:107 as indicator for $\mathrm{C}$ uptake into Cyanobacteria $\left(\mathrm{C}_{\mathrm{CY} \text { (newly-fixed) }}\right)$ following the light incubations, as determined from ${ }^{13} \mathrm{C}$-labeling, versus the corresponding dissolved inorganic phosphate (DIP) at (•) Moore Creek (MC) and (₫) Huey Hollow (HH). $\mathrm{C}_{\mathrm{CY} \text { (newly-fixed) }}$ exhibited a significant effect with DIP (GLM: $\chi^{2}{ }_{1,9}=22.6456$, $p=0.0004$ ) such that $C_{C Y(n e w l y-f i x e d)}$ increased with DIP. Lines represent the least squares regression results for MC (- - -) and $\mathrm{HH}(-)$

\section{DISCUSSION}

\section{Source of DOC released from epilithic stream biofilms and relationship to NPP}

This study is one of the first to directly link epilithic biofilm production to a significant in-stream source of DOC. Net release of DOC only occurred in the light enclosures with NPP, the one explanatory factor exhibiting a significant effect on the variation in net DOC release in our study. The higher rates of epilithic biofilm NPP at Moore Creek probably contributed to the elevated DOC concentrations relative to Huey Hollow, where both NPP and DOC were lower and where terrestrial sources are probably more important (Ziegler \& Brisco 2004).

Variation in the net DOC release by these biofilms may have been in response to variations in nutrient availability, perhaps through overflow mechanisms in the phototrophs (Myklestad et al. 1972) and/or alteration of enzymatic activities and degradation of terrestrial organic matter by heterotrophs supported by phototrophic C (Espeland \& Wetzel 2001). The release of DOC from the epilithic biofilms in the present study represented between 8 and $45 \%$ of NPP, well within the range reported for extracellular release of DOC by freshwater and marine planktonic communities $(<1$ to $50 \%$; Hellebust 1967, Nalewajko \& Schindler 1976, Cole et al. 1982, Baines \& Pace 1992). The proportion of NPP released as DOC varied with site, suggesting
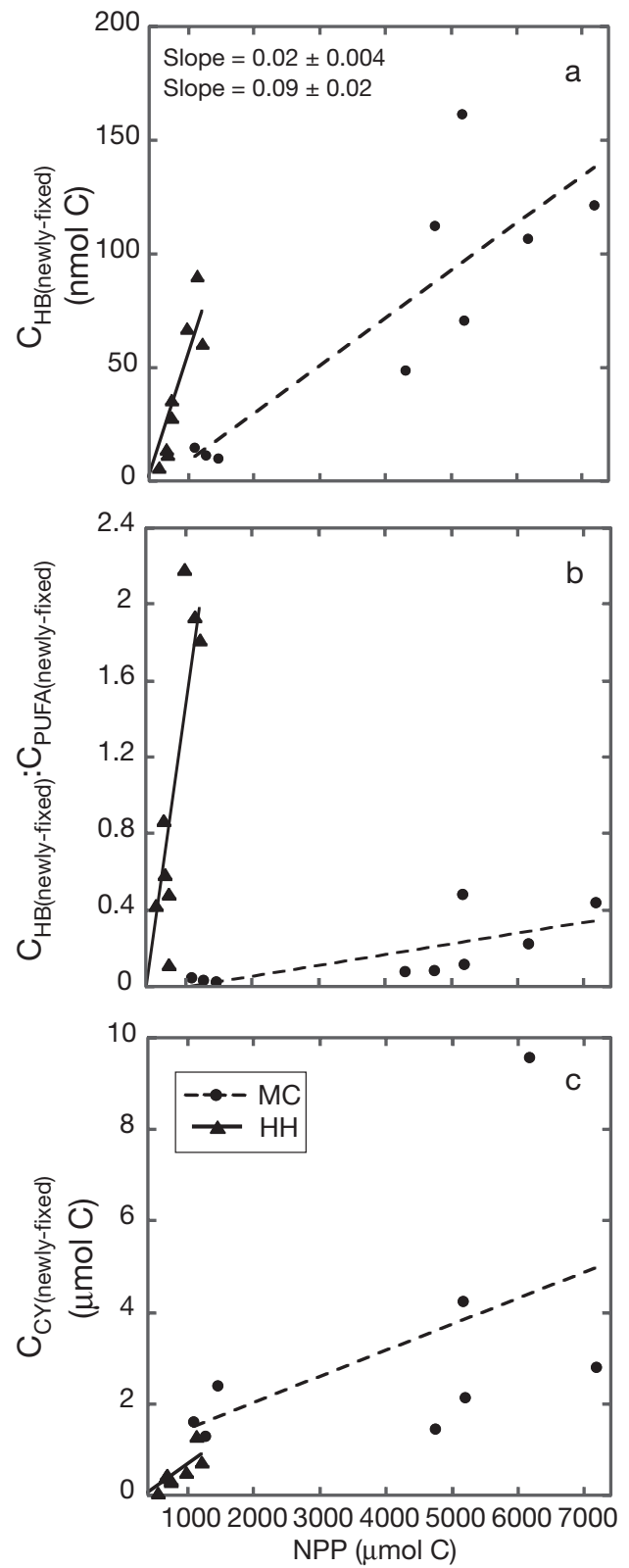

Fig. 6. Newly-fixed $\mathrm{C}$, determined from ${ }^{13} \mathrm{C}$-labeling following the light incubation period and plotted against net primary production (NPP), in (a) the sum of the PLFAs i15:0 and a15:0 as an indicator for $\mathrm{C}$ in heterotrophic bateria $\left(\mathrm{C}_{\mathrm{HB} \text { (newly- }}\right.$ fixed) $)$, (b) the ratio of $\mathrm{C}_{\mathrm{HB}(\text { newly-fixed) }}$ to the sum of all polyunsaturated fatty acids (PUFAs) $\left(\mathrm{C}_{\mathrm{HB} \text { (newly-fixed): }} \mathrm{C}_{\mathrm{PUFA} \text { (newly-fixed) }}\right.$ ), and

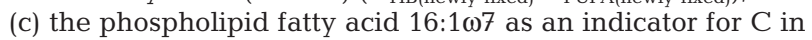
cyanobacteria $\left(\mathrm{C}_{\mathrm{CY} \text { (newly-fixed) }}\right)$. Values are shown for $(\bullet)$ Moore Creek $(\mathrm{MC})$ and $(\boldsymbol{\Delta})$ Huey Hollow $(\mathrm{HH})$. $\mathrm{C}_{\mathrm{HB}(\text { newly-fixed) }}$ exhibited a significant effect, as determined by GLM, with stream site $\left(\chi_{1,14}^{2}=14.5628, \mathrm{p}=0.0035\right), \mathrm{NPP}\left(\chi_{1,14}^{2}=15.5028, \mathrm{p}=\right.$ $0.0027)$ and stream site $\times \operatorname{NPP}\left(\chi_{1,14}^{2}=9.7946, p=0.0135\right)$. $\mathrm{C}_{\mathrm{HB} \text { (newly-fixed) }} \mathrm{C}_{\mathrm{PUFA} \text { (newly-fixed) also exhibited a significant }}$ stream site $\left(\chi_{1,14}^{2}=10.9788, p=0.00955\right), \operatorname{NPP}\left(\chi_{1,14}^{2}=7.1351\right.$, $\mathrm{p}=0.02945)$ and stream site $\times \operatorname{NPP}\left(\chi_{1,14}^{2}=6.8644, \mathrm{p}=\right.$ $0.03195)$ effect, while $C_{C Y(n e w l y-f i x e d)}$ did not exhibit any stream $(p=0.3749)$, NPP $(p=0.2795)$ or stream site $\times$ NPP $(p=0.9681)$ effects. Lines represent the least squares regression results for MC (- - ) and HH (-); slopes \pm SD are provided for regressions in (a) 
that within-stream factors may exert control over the proportion of DOC released. In fact, the proportion of NPP released as DOC was greatest when N availability was lowest and when light availability was highest in Huey Hollow and also lowest when $\mathrm{P}$ availability was lowest in Moore Creek (Fig. 2). The distinct difference was probably due in part to differences in $\mathrm{N}$ and $\mathrm{P}$ limitation of biofilm phototrophs in the 2 streams. More specifically, the observed increase in retention of newly-fixed $\mathrm{C}$ in the bulk biofilm and ubiquitous PLFA 16:0, and the decrease in newly-fixed $C$ released as DOC with increasing stream water DIP, further support the idea that $\mathrm{P}$ limitation increased the release of newly-fixed $\mathrm{C}$ from these biofilms.

Nutrient stoichiometry may be one key factor regulating microbial and food web dynamics in stream ecosystems (Frost et al. 2002, Dodds 2006), and DOC release from the stream biofilms, as studied here, may represent one mechanism by which biofilm communities respond to changes in stream nutrient stoichiometry. Further, the release of DOC from phototrophic communities or individuals, occurring through extracellular release of photosynthates or through grazing activities, can be ecologically important to heterotrophs in the aquatic environment (Brock \& Clyne 1984, Baines \& Pace 1992), which in turn regulates nutrient cycling. The high proportion of newly-fixed $\mathrm{C}$ in the DOC released from the Moore Creek biofilms indicates rapid release of photosynthate, probably through a combination of exudation and inefficient or sloppy grazing of the biofilm.

In contrast to Moore Creek, the lower proportion of newly-fixed C released as DOC in Huey Hollow suggests that biofilm activity may have been stimulated by greater retention of newly-fixed $\mathrm{C}$ by the biofilm community in this stream, where far less inefficient or sloppy feeding by grazers probably occurred. The presence of both light and nutrient regulation of net DOC release as a proportion of NPP in Huey Hollow and lack of such a clear relationship in Moore Creek (Fig. 2) is congruent with the idea that sloppy feeding was probably not as important in regulating DOC releases in Huey Hollow as it may have been in Moore Creek. Rather, NPP may have stimulated overall microbial activity in the Huey Hollow biofilms through the exchange of photosynthates, leading to increased degradation of terrestrial or 'older' autotrophic sources of C. Mutualistic relationships between algae and bacteria in epiphytic and epilithic biofilms can provide a key mechanism to support nutrient recycling and high rates of production in aquatic environments (Haack \& McFeters 1982, Neely \& Wetzel 1995). Further, extracellular activities by heterotrophic bacteria can be greater in more algal-rich stream biofilms, suggesting that photosynthates can stimulate organic matter degradation (Romani \& Sabater 2000), even providing an important source of nutrients to heterotrophic bacteria (Espeland \& Wetzel 2001). The importance of this exchange, however, is probably dependent upon grazing activities that may regulate the overall retention of newly-fixed $\mathrm{C}$ in these biofilms. Just as greater nutrient retention and cycling is probably responsible for the maintenance of productivity in nutrient-replete streams (Mulholland et al. 2001), longer retention and cycling of photosynthates may also be important to the maintenance of microbial activity in nutrient-poor stream biofilms. Results from the present study suggest the need for further research on the relative importance of sloppy feeding versus biofilm algal-bacterial interactions on DOC cycling in streams experiencing varied stoichiometries.

\section{Composition and activity of autotrophs in epilithic stream biofilms}

Algal community structure in streams can be more sensitive to external forcing, such as nutrient ratios and loading, than to bulk algal parameters such as chl a:C or C:N ratios (Stelzer \& Lamberti 2001). Little information exists on stream algal DOC exudation, but excretion of DOC from phytoplankton and the microphytobenthos in nearshore marine sediments appears to be dependent upon species composition (Myklestad 1995). Epipelic species in the microphytobenthos in nearshore marine sediments, for example, are documented to excrete up to $60 \%$ of C assimilated (Smith \& Underwood 2000), while epipsammic species have been found to excrete little $(<5 \%$, Cook et al. 2007). Additionally, grazing rates can both influence and be influenced by algal composition (Elwood et al. 1981, Haglund \& Hillebrand 2005), which in turn may affect the release of DOC through inefficient or 'sloppy' grazing, as has been observed with leaf litter (Meyer \& O'Hop 1983).

Variation in the activity of the autotrophs may have contributed to differences in the $\mathrm{C}$ cycling in the biofilms of the 2 study streams. The differential labeling of the autotrophic PLFAs between the 2 study streams suggests that differences in the composition of active phototrophs could have influenced $\mathrm{C}$ cycling in these stream biofilms. The greater release of newlyfixed C as DOC in Moore Creek, for example, may have been supported by biofilms richer in active green algae, as indicated by greater amounts of newly-fixed $\mathrm{C}$ in the green algal PLFA 18:3 03 . The lack of any nutrient or light control of green algal activity, as assessed here, precludes us from being able to specify any physiochemical regulation of green algal activities between the 2 study streams. It is, however, congruent 
with the idea that sloppy feeding may have been more important in Moore Creek since such inefficient grazing could have superceded any physiochemical or bottom-up control of green algal C. In contrast, newlyfixed $C$ in 16:1 107 , which is indicative of an increase in cyanobacteria with both increased DIP and light availability, suggests some role of nutrient status in regulating the fixation and retention of $\mathrm{C}$ in cyanobacteria in these biofilms. It is beyond the scope of this study to clearly link the variation in DOC release with the composition of active algal communities in these biofilms. However, the wealth of information on the effects of nutrient enrichment on stream algal composition (Rosemond et al. 1993, Hall et al. 2007) and invertebrate activities and composition (Cross et al. 2005, Gafner \& Robinson 2007), combined with the suggested link to variation in C-cycling presented here, indicates the need for targeted work to demonstrate the potential role of inefficient grazing as a factor contributing to stream water DOC fluxes. Such investigations would nicely extend those that have demonstrated the role of invertebrate grazers and shredders in releasing DOC from allochthonous sources in streams (Meyer \& O'Hop 1983) to autochthonous sources.

\section{Algal-bacterial coupling in epilithic stream biofilms}

The relationship between biofilm algae and bacteria can be quite important to the function of stream communities, which are critical regulators of nutrient cycling (Lock et al. 1984, Ishida et al. 2007). Accrual of biofilm biomass can isolate microorganisms in the biofilm from overlying waters, a source of new nutrients and organic matter. This typically increases the dependency of heterotrophic bacteria on organic carbon supplied from algae and cyanobacteria (Murray et al. 1986, Neely \& Wetzel 1995). On the other hand, maintenance of primary production in epilithic or benthic biofilms is also dependent upon internal cycling of nutrients such that a mutualistic relationship exists between phototrophs and heterotrophs (Wetzel 1990, 1993). Accordingly, recent studies have suggested that algal-bacterial relationships in stream biofilms can be greatly influenced by nutrient levels (Rier \& Stevenson 2002, Scott et al. 2008). In the present study, the presence of some small net nutrient uptake rates and lack of net release of inorganic nutrients from biofilms suggest tight recycling of $\mathrm{N}$ and $\mathrm{P}$ within the biofilms studied. DOC, on the other hand, was released during light incubations, and the proportion of newly-fixed C incorporated into bacterial PLFA ia 15:0 suggests differences in algal-bacterial coupling with regard to $\mathrm{C}$ in the 2 study streams.
It is important to distinguish between cyanobacterial $\mathrm{C}$ fixation and use of photosynthate by heterotrophic bacteria when interpreting the greater proportion of newly-fixed C in bacterial PLFAs in the Huey Hollow biofilms relative to those of Moore Creek. The ia15:0 PLFAs are not typically found in cyanobacteria (Parker et al. 1967, Merritt et al. 1991, Ahlgren et al. 1992), but have been found in some free-living species (Caudales et al. 2000). Additions of ${ }^{13} \mathrm{C}$-glucose at tracer levels in stream water in short-term dark enclosure incubations in other nearby headwater streams confirm the heterotrophic origins of the PLFA ia15:0 in the epilithic biofilms in this region (D. R. Lyon \& S. E. Ziegler unpubl. data). Furthermore, the greater proportion of NPP incorporated as newly-fixed C into biofilm ia15:0 in Huey Hollow relative to Moore Creek (Fig. 6a) and lack of such an increase in newly-fixed $C$ in 16:1 107 in the Huey Hollow biofilms (Fig. 6c) support the interpretation that heterotrophic bacteria accessed a larger proportion of NPP in Huey Hollow.

Evidence for greater retention of newly-fixed $\mathrm{C}$ by the biofilm bacteria in Huey Hollow compared with Moore Creek suggests that photosynthates may have stimulated greater heterotrophic activity relative to productivity in these biofilms. Heterotrophic bacterial activity can be linked to algal activity in biofilms, and such mutualistic interactions may be critical to nutrient processing and food webs in stream ecosystems (Hepinstall \& Fuller 1994). The Huey Hollow biofilms exhibited greater heterotrophic activity, as revealed by greater total community respiration, in spring and summer relative to Moore Creek, and the PLFA labeling results also suggest greater retention of newlyfixed $\mathrm{C}$ by heterotrophic bacteria in the Huey Hollow biofilms. The quantity of newly-fixed $\mathrm{C}$ in the bulk biofilm following the light incubations was significantly related to NPP, indicating that nearly $70 \%$ of NPP ended up in the stream biofilms. This is congruent with net DOC release representing between 8 and $45 \%$ of NPP. The proportion of newly-fixed C into the PLFA 16:0, representing a ubiquitous microbial biomarker, relative to NPP indicated that a greater proportion of newly-fixed $\mathrm{C}$ was retained in the microbial biofilm biomass in Huey Hollow relative to Moore Creek. More specifically, newly-fixed C incorporated into biofilm heterotrophic bacterial PLFAs relative to NPP was greater in Huey Hollow compared with that in Moore Creek, and suggested that heterotrophic bacteria probably accessed 4 times more of the NPP in the Huey Hollow biofilms (Fig. 6a). This, in conjunction with the greater proportion of newly-fixed $\mathrm{C}$ in heterotrophic bacterial PLFAs relative to algal PLFAs (PUFAs; Fig. 6b) in Huey Hollow, clearly indicates a tighter algal-bacterial coupling in the nutrient-deplete versus nutrient-replete stream biofilms in the present 
study. The greater release of newly-fixed C as DOC from the biofilms in the more nutrient-rich Moore Creek, perhaps through exudation and inefficient or sloppy grazing, probably decoupled heterotrophic bacteria from newly-fixed $\mathrm{C}$ in those biofilms.

\section{CONCLUSIONS}

This study indicates that epilithic stream biofilms can be important sources of DOC, and that $\mathrm{C}$ cycling greatly varied between the 2 contrasting study streams in 2 significant ways. First, a larger proportion of DOC released from biofilms to stream water in the nutrientrich stream is derived from new photosynthates, reducing the availability of this source of NPP to biofilm heterotrophic bacteria. Second, a greater proportion of NPP is retained in the heterotrophic bacterial PLFAs of the biofilms in the more nutrient-deplete stream. Nutrient enrichment of headwater streams may greatly alter the capacity of these ecosystems to process nutrients not only through nutrient saturation (Hamilton et al. 2001), but also through related changes in the internal $\mathrm{C}$ cycling of epilithic biofilms. Future studies should focus on the role of nutrient enrichment on $\mathrm{C}$ cycling within epilithic stream biofilms as a means to further understand the effects of such changes on stream biogeochemistry.

Acknowledgements. We thank J. A. Baird, L. Conaway, J. H. Fiser, T. Johnson and T. Millican for their assistance in the field and laboratory, and J. Cox and G. Piercey for their assistance with some of the stable isotope analyses. Thanks go to D. Schneider for all of his assistance and advice on statistical analyses. This paper was improved by comments from S. Billings, G. Piercey, 3 anonymous reviewers and the handling editor. Funding was provided by National Science Foundation (DEB 0445357).

\section{LITERATURE CITED}

Ahlgren G, Gustafsson IB, Boberg M (1992) Fatty-acid content and chemical-composition of fresh-water microalgae. J Phycol 28:37-50

Baines SB, Pace ML (1992) The production of dissolved organic matter by phytoplankton and its importance to bacteria: patterns across marine and freshwater systems. Limnol Oceanogr 36:1078-1090

Baker MA, Dahm CN, Valett HM (1999) Acetate retention and metabolism in the hyporheic zone of a mountain stream. Limnol Oceanogr 44:1530-1539

Battin TJ, Butturini A, Sabater F (1999) Immobilization and metabolism of dissolved organic carbon by natural sediment biofilms in a Mediterranean and temperate stream. Aquat Microb Ecol 19:297-305

Benner R (2003) Molecular indicators of the bioavailability of dissolved organic matter. In: Findlay SEG, Sinsabaugh RL (eds) Aquatic ecosystems: interactivity of dissolved organic matter. New York, p 121-137
Bernhardt ES, Likens GE (2002) Dissolved organic carbon enrichment alters nitrogen dynamics in a forest stream. Ecology 83:1689-1700

Boschker HTS, Middelburg JJ (2002) Stable isotopes and biomarkers in microbial ecology. FEMS Microbiol Ecol 40: 85-95

Bothwell ML (1985) Phosphorus limitation of lotic periphyton growth rates: an intersite comparison using continuousflow troughs (Thompson River system, British Columbia). Limnol Oceanogr 30:527-542

> Bott TL, Kaplan LA, Kuserk FT (1984) Benthic bacterial biomass supported by streamwater dissolved organic matter. Microb Ecol 10:335-354

> Brisco S, Ziegler S (2004) Effects of solar radiation on the utilization of dissolved organic matter (DOM) from two headwater streams. Aquat Microb Ecol 37:197-208

Brock TD, Clyne J (1984) Significance of algal excretory products for growth of epilimnetic bacteria. Appl Environ Microbiol 47:731-734

> Caudales R, Wells JM, Butterfield JE (2000) Cellular fatty acid composition of cyanobacteria assigned to subsection II, order Pleurocapsales. Int J Syst Evol Microbiol 50: 1029-1034

Cole JJ, Likens GE, Strayer DL (1982) Photosynthetically produced dissolved organic carbon: an important carbon source for planktonic bacteria. Limnol Oceanogr 27: 1080-1090

Cook PLM, Wenzhofer F, Glud RN, Janssen F, Huettel M (2007) Benthic solute exchange and carbon mineralization in two shallow subtidal sandy sediments: effect of advective pore-water exchange. Limnol Oceanogr 52: 1943-1963

Cross WF, Benstead JP, Frost PC, Thomas SA (2005) Ecological stoichiometry in freshwater benthic systems: recent progress and perspectives. Freshw Biol 50:1895-1912

Dobbs FC, Findlay RH (1993) Analysis of microbial lipids to determine biomass and detect the response of sedimentary microorganisms to disturbance. In: Kemp PF, Sherr BF, Sherr EB, Cole JJ (eds) Current methods in aquatic microbial ecology. Lewis Publishers, Baton Rouge, FL, p 347-358

Dodds WK (2006) Eutrophication and trophic state in rivers and streams. Limnol Oceanogr 51:671-680

Dodds WK, Evans-White MA, Gerlanc NM, Gray L and others (2000) Quantification of the nitrogen cycle in a prairie stream. Ecosystems 3:574-589

> Elwood JW, Newbold JD, Trimble AF, Stark RW (1981) The limiting role of phosphorus in a woodland stream ecosystem: effects of $\mathrm{P}$ enrichment on leaf decomposition and primary producers. Ecology 62:146-158

Espeland EM, Wetzel RG (2001) Effects of photosynthesis on bacterial phosphatase production in biofilms. Microb Ecol 42:328-337

Findlay RH, Dobbs FC (1993) Quantitative description of microbial communities using lipid analysis. In: Kemp PF, Sherr BF, Sherr EB, Cole JJ (eds) Current methods in aquatic microbial ecology. Lewis Publishers, Boca Raton, FL, p 271-284

> Findlay S, Howe K, Fontvielle D (1993) Bacterial-algal relationships in autotrophic and heterotrophic streams in the Hubbard Brook Experimental Forest. Ecology 74: 2326-2336

- France R (1995) Critical examination of stable isotope analysis as a means for tracing carbon pathways in stream ecosystems. Can J Fish Aquat Sci 52:651-656

$>$ Frost PC, Stelzer RS, Lamberti GA, Elser JJ (2002) Ecological stoichiometry of trophic interactions in the benthos: 
understanding the role of $\mathrm{C}: \mathrm{N}: \mathrm{P}$ ratios in lentic and lotic habitats. J N Am Benthol Soc 21:515-528

Gafner K, Robinson CT (2007) Nutrient enrichment influences the responses of stream macroinvertebrates to disturbance. J N Am Benthol Soc 26:92-102

Haack TK, McFeters GA (1982) Microbial dynamics of an epilithic mat community in a high alpine stream. Appl Environ Microbiol 43:702-707

Haglund AL, Hillebrand H (2005) The effect of grazing and nutrient supply on periphyton associated bacteria. FEMS Microbiol Ecol 52:31-41

Hall SR, Leibold MA, Lytle DA, Smith VH (2007) Grazers, producer stoichiometry, and the light:nutrient hypothesis revisited. Ecology 88:1142-1152

Hamilton SK, Tank JL, Raikow DF, Wollheim WM, Peterson BJ, Webster JR (2001) Nitrogen uptake and transformation in a midwestern US stream: a stable isotope enrichment study. Biogeochemistry 54:297-340

Hellebust JA (1967) Excretion of organic compounds by cultured and natural populations of marine phytoplankton. In: Lauff GH (ed) Estuaries. Am Assoc Adv Sci Pub 83, Washington, DC, p 361-366

Hepinstall JA, Fuller RL (1994) Periphyton reactions to different light and nutrient levels and the response of bacteria to these manipulations. Arch Hydrobiol 131:161-173

Hoffmann JP (2004) Generalized linear models an applied approach. Pearson, Boston, MA

Ishida CK, Arnon S, Peterson CG, Kelly JJ, Gray KA (2007) Influence of algal community structure on denitrification rates in periphyton cultivated on artificial substrata. Microb Ecol 56:140-152

Kaplan LA, Bott TL (1983) Microbial heterotropic utilization of dissolved organic matter in a piedmont stream. Freshw Biol 13:363-377

Kaplan LA, Bott TL (1989) Diel fluctuations in bacterial activity on streambed substrata during vernal algal blooms: effects of temperature, water chemistry, and habitat. Limnol Oceanogr 34:718-733

Kaplan LA, Newbold JD (1993) Biogeochemistry of dissolved organic carbon entering streams. In: Ford TE (ed) Aquatic microbiology: an ecological approach. Blackwell Scientific, Oxford, p 139-165

Lindsey JK (1997) Applying generalized models. SpringerVerlag, New York

Lyons DR, Ziegler SE (2009) Carbon cycling within epilithic biofilm communities across a nutrient gradient of headwater streams. Limnol Oceanogr 54(2):439-449

> Lock MA, Wallace RR, Costerton JW, Ventullo RM, Charlton SE (1984) River epilithon: toward a structural-functional model. Oikos 42:10-22

Lohman K, Jones JR, Baysingerdaniel C (1991) Experimental evidence for nitrogen limitation in a northern Ozark stream. J N Am Benthol Soc 10:14-23

Merritt MV, Rosenstein SP, Rachel CL, Chou HS, Allen MM (1991) A comparison of the major lipid classes and fattyacid composition of marine unicellular Cyanobacteria with fresh-water species. Arch Microbiol 155:107-113

Meyer JL, O'Hop J (1983) Leaf-shredding insects as a source of dissolved organic carbon in headwater streams. Am Midl Nat 109:175-183

Moran MA, Hodson RE (1989) Formation and bacterial utilization of dissolved organic carbon derived from detrital lignocellulose. Limnol Oceanogr 34:1034-1047

> Mulholland PJ, Fellows CS, Tank JL, Grimm NB and others (2001) Inter-biome comparison of factors controlling stream metabolism. Freshw Biol 46:1503-1517

Murray RE, Cooksey KE, Priscu JC (1986) Stimulation of bac- terial DNA synthesis by algal exudates in attached algalbacterial consortia. Appl Environ Microbiol 52:1177-1182

Myklestad SM (1995) Release of extracellular products by phytoplankton with special emphasis on polysaccharides. Sci Total Environ 165:155-164

Myklestad S, Haug A, Larsen B (1972) Production of carbohydrates by the marine diatom Chaetoceros affinis var. willei (Gran) Hustedt. II. Preliminary investigation of the extracellular polysaccharide. J Exp Mar Biol Ecol 9:137-144

Nalewajko C, Schindler DW (1976) Primary production, extracellular release, and heterotrophy in two lakes in the ELA, northwestern Ontario. J Fish Res Board Can 33: 219-226

> Neely RK, Wetzel RG (1995) Simultaneous use of ${ }^{14} \mathrm{C}$ and ${ }^{3} \mathrm{H}$ to determine autotrophic production and bacteria protein production in periphyton. Microb Ecol 30:227-237

Parker PL, Van Baalen C, Maurer L (1967) Fatty acids in eleven species of blue-green algae: geochemical significance. Science 155:707-708

Petersen JC, Femmer SR (2002) Periphyton communities in streams of the Ozark Plateaus and their relations to selected environmental factors. Water-Resources Investigations Report 02-4210. US Geological Survey, National Water-Quality Assessment Program, Little Rock, AR

Peterson BJ, Wollheim WM, Mulholland PJ, Webster JR and others (2001) Control of nitrogen export from watersheds by headwater streams. Science 292:86-90

Rier ST, Stevenson RJ (2002) Effects of light, dissolved organic carbon, and inorganic nutrients on the relationship between algae and heterotrophic bacteria in stream periphyton. Hydrobiologia 489:179-184

Romani AM, Sabater S (2000) Influence of algal biomass on extracellular activity in river biofilms. Microb Ecol 41:16-24

> Rosemond AD, Mulholland PJ, Elwood JW (1993) Top-down and bottom-up control of stream periphyton-effects of nutrients and herbivores. Ecology 74:1264-1280

Sallal AK, Nimer NA, Radwan SS (1990) Lipid and fatty-acid composition of fresh-water cyanobacteria. J Gen Microbiol 136:2043-2048

Scott TJ, Back JA, Taylor JM, King RS (2008) Does nutrient enrichment decouple algal-bacterial production in periphyton? J N Am Benthol Soc 27:332-344

Smith DJ, Underwood GJC (2000) The production of extracellular carbohydrates by estuarine benthic diatoms: the effects of growth phase and light and dark treatment. J Phycol 36:321-333

> Sobczak WV, Hedin LO, Klug MJ (1998) Relationships between bacterial productivity and organic carbon at a soil-stream interface. Hydrobiologia 386:45-53

Stelzer RS, Lamberti GA (2001) Effects of N:P ratio and total nutrient concentration on stream periphyton community structure, biomass, and elemental composition. Limnol Oceanogr 46:356-367

Volk CJ, Volk CB, Kaplan LA (1997) Chemical composition of biodegradable dissolved organic matter in streamwater. Limnol Oceanogr 42:39-44

Warren CE, Wales AH, Davis GE, Doudoroff P (1964) Trout production in an experimental stream enriched with sucrose. J Wildlife Man 28:617-660

Webster JR, Gurtz ME, Hains JJ, Meyer JL, Swank WT, Waide JB, Wallace JB (1983) Stability of stream ecosystems. In: Barnes JR, Minshall GW (eds) Stream ecology. Plenum Press, p 355-395

Wetzel RG (1990) Land-water interfaces: metabolic and limnological regulators. Int Ver Theor Angew Limnol Verh 24:6-24

Wetzel RG (1993) Microcommunities and microgradients: 
linking nutrient regeneration, microbial mutualism, and high sustained aquatic primary production. Neth J Aquat Ecol 27:3-9

White DC, Ringelberg DB (1998) Signature lipid biomarker analysis. In: Burlage RS, Atlas R, Stahl D, Geesey G, Sayler G (eds) Techniques in microbial ecology. Oxford University Press, New York, p 255-272

Editorial responsibility: Hugh MacIntyre, Dauphin Island, Alabama, USA
Wood BJB (1988) Lipids of algae and protozoa. In: Ratledge C, Wilkinson SG (eds) Microbial lipids, Vol 1. Harcourt Brace Jovanovich, New York, p 807-867

Ziegler SE, Brisco SL (2004) Relationships between the isotopic composition of dissolved organic carbon and its bioavailability in contrasting Ozark streams. Hydrobiologia 513:153-169

Submitted: April 24, 2008; Accepted: March 16, 2009

Proofs received from author(s): June 8, 2009 